\title{
A Systematic Review of Closed Head Injury Models of Mild Traumatic Brain Injury in Mice and Rats
}

\author{
Colleen N. Bodnar, ${ }^{1,2}$ Kelly N. Roberts, ${ }^{1,2}$ Emma K. Higgins, ${ }^{1,2}$ and Adam D. Bachstetter ${ }^{1,2}$
}

\begin{abstract}
Mild TBI (mTBI) is a significant health concern. Animal models of mTBI are essential for understanding mechanisms, and pathological outcomes, as well as to test therapeutic interventions. A variety of closed head models of mTBI that incorporate different aspects (i.e., biomechanics) of the mTBI have been reported. The aim of the current review was to compile a comprehensive list of the closed head mTBI rodent models, along with the common data elements, and outcomes, with the goal to summarize the current state of the field. Publications were identified from a search of PubMed and Web of Science and screened for eligibility following PRISMA guidelines. Articles were included that were closed head injuries in which the authors classified the injury as mild in rats or mice. Injury model and animal-specific common data elements, as well as behavioral and histological outcomes, were collected and compiled from a total of 402 articles. Our results outline the wide variety of methods used to model mTBI. We also discovered that female rodents and both young and aged animals are under-represented in experimental mTBI studies. Our findings will aid in providing context comparing the injury models and provide a starting point for the selection of the most appropriate model of mTBI to address a specific hypothesis. We believe this review will be a useful starting place for determining what has been done and what knowledge is missing in the field to reduce the burden of mTBI.
\end{abstract}

Keywords: animal models; common data elements; concussion

\section{Introduction}

$\mathbf{M}$ ILD TRAUMATIC BRAIN INJURY (MTBI), caused by blunt trauma, acceleration, or deceleration forces, is a significant public health concern. ${ }^{1}$ In the United States, mTBI is estimated to occur in 1.6-3.8 million cases annually. ${ }^{2}$ Estimates of mTBI are under-reporting cases of mTBI attributed to the fact that many individuals who sustain a mTBI never seek medical treatment. ${ }^{3}$ Not only are incidences of mTBI on the rise- $62 \%$ increase in recreation-related $\mathrm{mTBI}$ cases over a 10 -year period ${ }^{4}$ - there is also a growing appreciation that a mTBI is not benign and the brain may not fully recover from the injury with time. The Department of Veterans Affairs and the Department of Defense Clinical Practice Guidelines and the World Health Organization guidelines classify a head injury as a mTBI according to the following criteria: normal structural imaging; loss of consciousness $<30 \mathrm{~min}$; alteration of consciousness less than $24 \mathrm{~h}$; post-traumatic amnesia of less than a day; and an initial Glasgow Coma Scale of $13-15 .^{5}$ By far, the majority of mTBIs are caused by a closed head injury. ${ }^{6}$ The Centers for Disease Control and Prevention (CDC) concluded there was the need for research to understand the full magnitude of mTBI incidence, risk factors, and strategies to reduce and improve mTBI outcomes. ${ }^{1}$ Much of this research begins with understanding the pathological and mechanistic changes of mTBI in pre-clinical models.

The use of animal models in TBI research is crucial. Many animal models have been developed over the last 80 years to replicate the different unique features of mTBI (e.g., emotional or cognitive symptoms), as well as biomechanical forces (e.g., impact or rotational). Although the overall number of experimental mTBI studies are small in number, they are steadily increasing at a rate reflecting the public's appreciation of the seriousness of mTBI. However, to paraphrase an expert in animal models of TBI, the field is a "wild west"; referring to the vast array of injury methods currently used to create a rodent model of mTBI. The aim of this systematic review is to compile a comprehensive list of TBI rodent models that are specific to mild closed head injury. Our review includes information about the methodology as well as the broad classes of outcomes. Understanding all of the different models, as well as pathologies associated with the model, is needed to propel the field forward by taming the wild west, building a framework of common data elements for future reporting of mTBI models, and uncovering gaps in our current knowledge base.

\footnotetext{
${ }^{1}$ Department of Neuroscience and ${ }^{2}$ Spinal Cord and Brain Injury Research Center, University of Kentucky, Lexington, Kentucky.

(C) Colleen N. Bodnar et al., 2019; Published by Mary Ann Liebert, Inc. This Open Access article is distributed under the terms of the Creative Commons License (http://creativecommons.org/licenses/by/4.0), which permits unrestricted use, distribution, and reproduction in any medium, provided the original work is properly credited.
} 


\section{Methods}

\section{Search criteria}

Our search criteria were established to be specific for mTBI models caused by a closed head injury. Following guidelines established by PRISMA, ${ }^{7}$ comprehensive searches (on May 15, 2018) of both PubMed and Web of Science were conducted using the following keyword search: mild TBI, concussion, closed head injury, rodent, mice, mouse, or rat; excluding controlled cortical impact, fluid percussion, or review articles. Using the advanced search tools on PubMed and Web of Science, both title and abstract were searched with the following Boolean search strategy: [(((()((rodent) OR rat) OR mouse) OR mice $))$ AND (((mild TBI) OR concussion) OR closed head injury))) NOT ((CCI) OR fluid percussion)]. From PubMed, 984 articles were given in the final results, and Web of Science produced 1336 articles. Both of these lists of articles were combined and duplicate references were removed, leaving 1890 articles (Fig. 1).

\section{Inclusion/exclusion criteria}

Abstracts and titles were screened by C.N.B. to include only peer-reviewed primary research reports specific for mild, closed head TBI only in rodents. All other types of articles were excluded. Blast injuries were excluded because, although military related blast injuries are a major cause of $\mathrm{mTBI}^{5}{ }^{5}$ the vast complexity of the different injury models used were beyond the scope of this review. ${ }^{8}$ All repeat injury models (85) were also considered beyond the scope of this review and were thus excluded (Fig. 1).

\section{Retrieval of information from full-text articles}

For collection of information on methods of each of these articles, a GoogleForm was used by C.N.B., K.N.R., and E.K.H. The

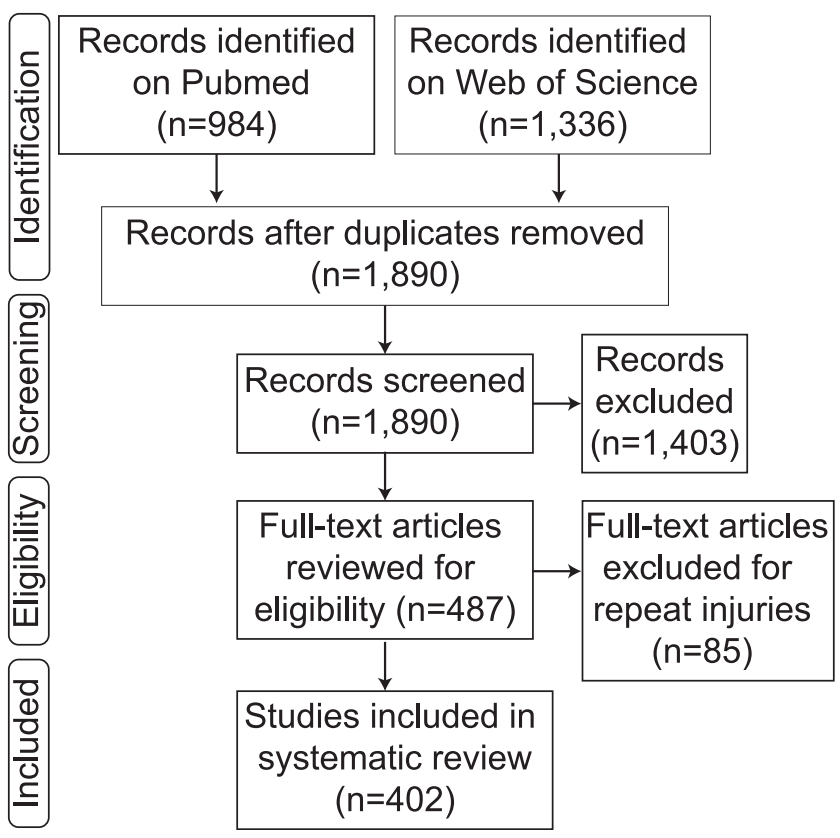

FIG. 1. Methods flow chart. Identification through searches on two separate web-based platforms yielded 1,890 articles which were screened by abstract and then eligibility was determined via full text examination to exclude 1,403 articles. Removing mTBI articles in which repeat injuries were sustained, a total of 402 single mTBI articles were included in our review. mTBI, mild traumatic brain injury. title, first author, last author, publication date, name of model, and references cited for the model were collected as general identifiers. For the method of injury induction, the following information was collected: injury device used, anesthesia use, surgery indicator, injury device type, head fixed with method of fixation, animal stabilization method, impact tip size, impact tip shape, impact tip material, impact surface, impact location, weight for drop, height for drop, tube composition, and the type of impact absorbent materials used (if any). Species, sex, and age of animals were also recorded. Finally, injury outcomes were collected, including mortality rate, righting reflex latency, neuroscore, motor deficits (open field, balance beam, rotarod, etc.), cognitive deficits (novel object, Morris water maze, radial arm water maze, Y/T maze, etc.), affective behavior deficits (elevated plus, social, sucrose preferences, etc.), and histology (cell and tissue changes, axonal injury markers, myelin markers, gliosis markers, etc.). Information on outcome variables was collected only between sham and control animals, not with any treatments done within the publication. If any treatments were done in the publications, the effects observed with treatment were not considered as content for this review.

\section{Results}

From searches on both PubMed and Web of Science, a total of 1890 articles were initially included. From this list, articles were screened for inclusion and exclusion criteria (Fig. 1). From this screening, the following articles were excluded: not including a TBI $(n=293)$; any article in which the skull was open and the brain surface was impacted (controlled cortical injury [CCI]/fluid percussion injury/or open skull; $n=125)$; any injury that was reported as moderate or severe $(n=237)$; duplicates missed in the original removal $(n=21)$; non-rodent models $(n=54)$; articles that used an in vitro or computational method $(n=63)$; blast injuries $(n=160)$; book chapters and reviews that were missed in the initial identification $(n=96)$; articles in another language $(n=24)$; articles with no explanation of their method, no sham animals, or not a full article $(n=20)$; and repeat injuries $(n=85)$. Finally, 402 articles were determined to be single, mild, TBIs to rodents. These 402 articles were then examined in full text and the common data elements were compiled (Fig. 1).

Of the 402 articles identified three main groups of injury models emerged. The largest group was weight drop models $(n=335){ }^{9-343}$ followed by piston-driven models $(n=43),{ }^{344-386}$ and then all "other" models $(n=25)^{387-411}$ (Fig. 2A). Please note that one article used both a weight drop model and a piston-driven model and was thus included in both of these groups. ${ }^{199}$ Within the pistondriven models and the "other" models, there was a wide variety of methods used (Fig. 2B,C). We compared how often the different categories of models were used over time to identify trends in usage (Fig. 2D). Weight drop models have featured prominently in the literature since the early 1990s. Piston-driven models gained popularity beginning in 2002. The "other" models were typically used early (1941-1987) and used more unconventional methods to induce mild brain injury. Once the weight drop models became more popular in the 1990s, this model became the dominant model in use during this time. Beginning in the mid-2000s, new models besides weight drop began to emerge, each attempting to model different aspects of mild TBI and increase the reproducibility of the injury model. At the same time, the number of weight drop publications plateaued.

From each article, the time post-injury at which the dependent variables were measured was collected (up to 1 day, up to 1 week, up to 1 month, over 1 month, or over 1 year). A vast majority were 


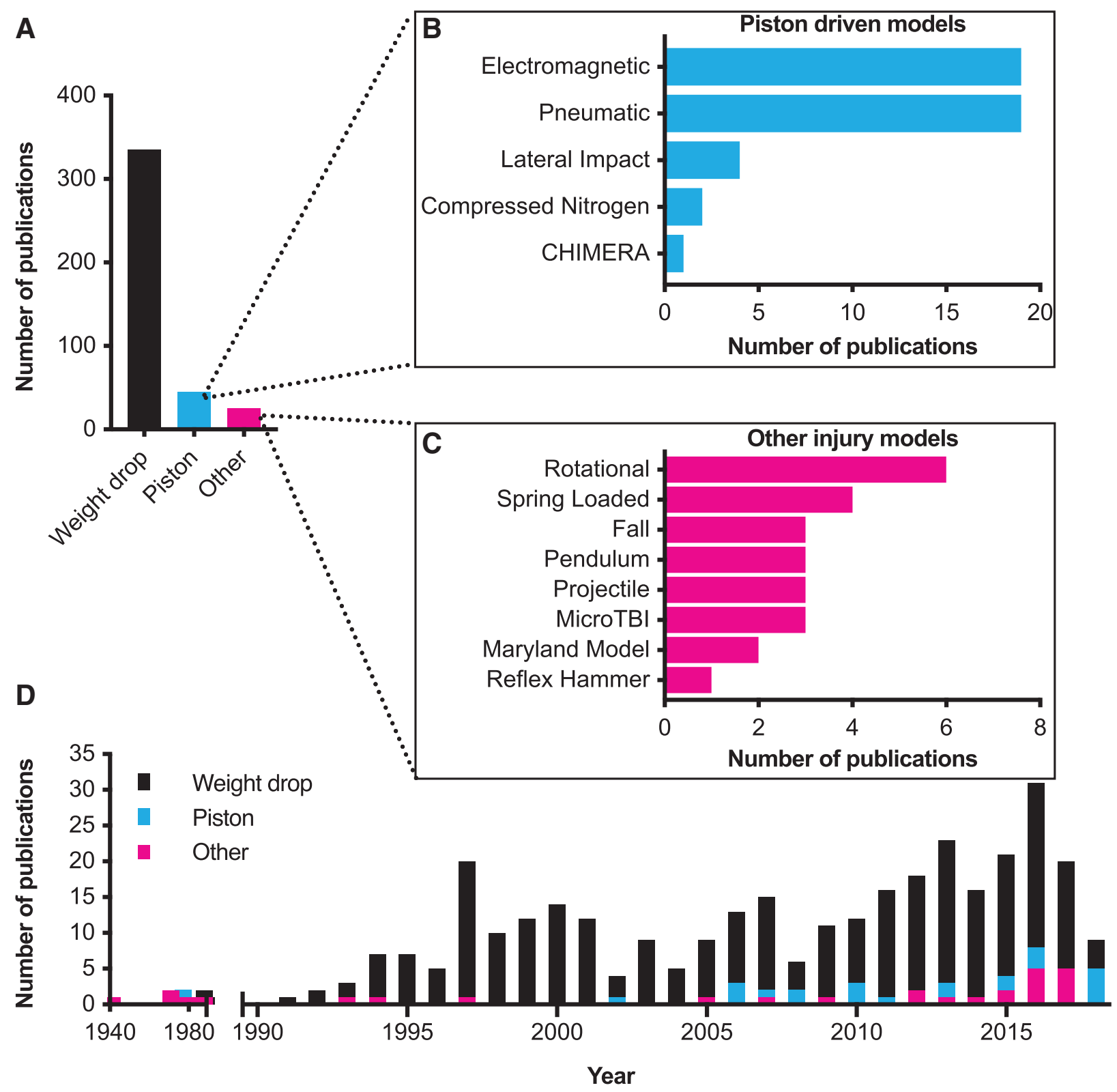

FIG. 2. Overall summary of included studies. Of the 402 articles included in our final analysis, 3 major categories of models were found (A). Within the piston category $(\mathbf{B})$ and the "other" models $(\mathbf{C})$ there was considerable variability. A breakdown by year of publication (D) demonstrated the weight drop model over the last four decades and the increase in use of piston driven models over the last decade. TBI, traumatic brain injury. Color image is available online.

recorded under a month, with $39 \%$ reporting up to 1 day postinjury, $35 \%$ reporting up to a week after injury, and $19 \%$ reporting up to 1 month after mTBI (Supplementary Appendix [SA] 0.1). Only 24 articles reported dependent variable measurements over a month, and only two publications reported measurements after a year (SA 0.1) (see online supplementary material).

\section{Weight drop model}

The weight drop model consists of dropping a projectile of specified characteristics through a tube at a specified height onto the head of the animal (Fig. 3A). We found considerable variation in the reported weight of the projectile (Figs. 3A and 4A) and drop height of the projectile (Figs. 3A and $4 \mathrm{~B}$ ) between different pub- lications. Additional model-specific common data elements that we captured and varied between different publications included: 1) if the mice were anesthetized at the time of impact; 2) if surgery was performed; 3) direct versus indirect impact to the skull (Figs. 3F and 4C); 4) impact location; 5) if the head was immobilized (Figs. 3G and 4D); 6) the surface the animal was placed on (Fig. 3A,H); 7) projectile shape; and 8 ) projectile material. Animal-specific common data elements that we captured included 1) sex of the animals (Fig. 4E) and 2) age of the animals (Fig. 4F).

Weight drop model: animal-specific common data elements. The reported animal-specific common data elements for the weight drop method showed remarkably little variation in sex or age of the animals used. The use of rats and mice occurred at an 


\section{A Weight drop Model B Piston driven Model}

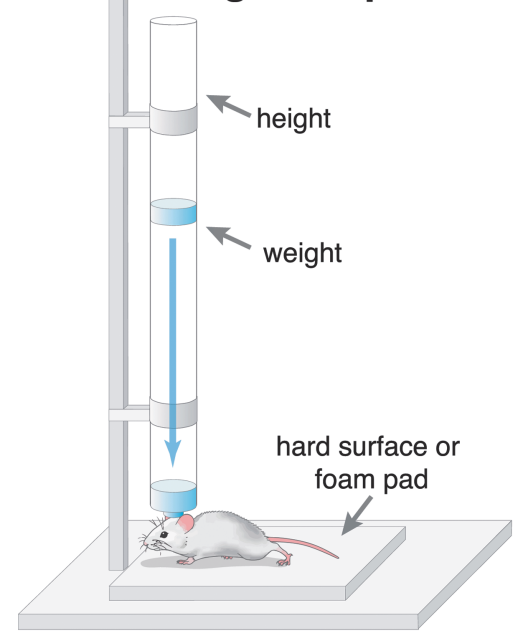

$\mathbf{F}$

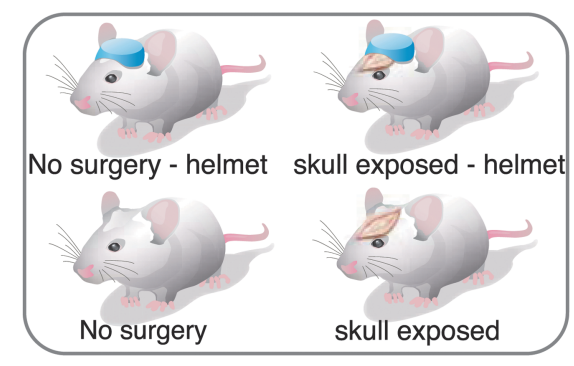

G

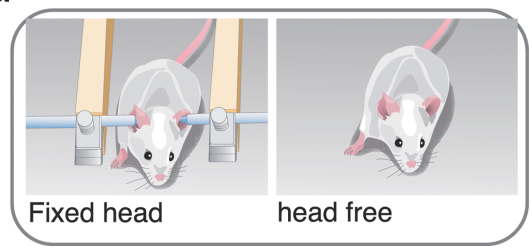

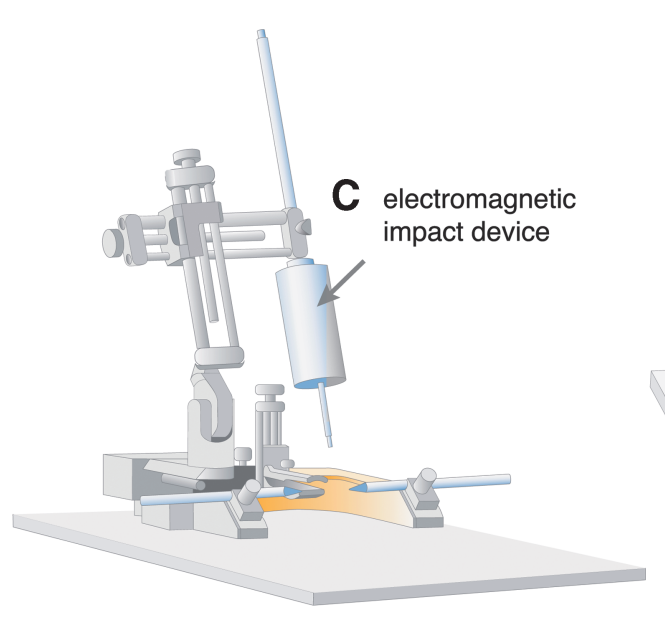

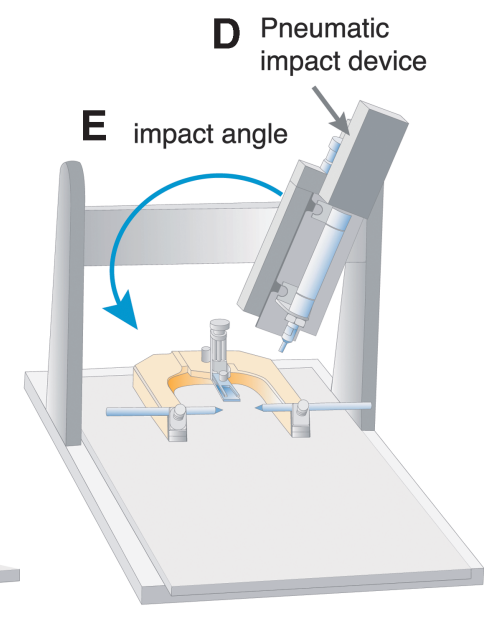

H

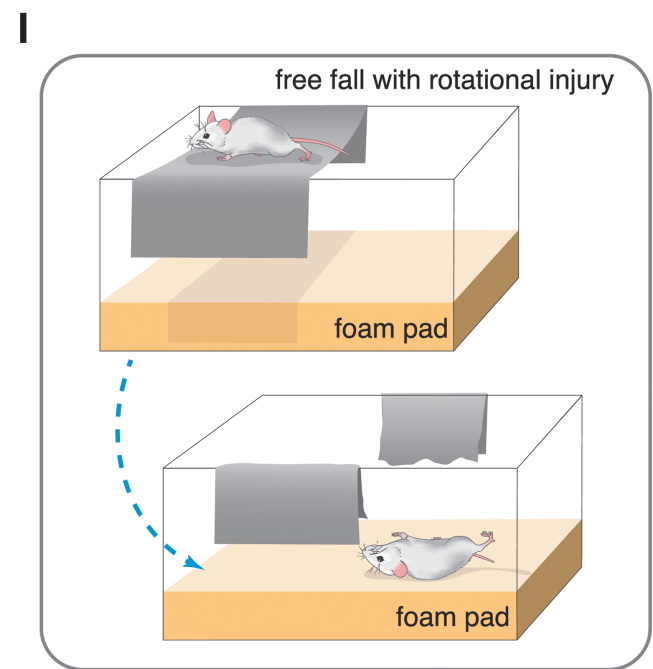

FIG. 3. Example experimental set-up for weight drop and piston mTBI models. In the weight drop model (A), a variable weight is dropped from a variable height, onto the head of the animal and the animal can be on either a hard surface or a foam pad. Piston driven models $(\mathbf{B})$, use either an electromagnetic $(\mathbf{C})$ or a pneumatic $(\mathbf{D})$ driven piston that is set to a specified velocity and impact depth and strikes the head of the animal. In piston driven models, the impact angle (E) can vary between study designs. In both the weight drop and the piston driven models the impact surface can vary with either a helmet or no helmet on the intact scalp or the exposed skull (F). Further, the head can be either fixed or free to rotate after the impact $(\mathbf{G})$. The impact tip which contacts the head of the animal to induce injury can be either flexible or rigid $(\mathbf{H})$ causing different injury biomechanics. An emerging model utilizes rotation following impact by placing the animal on a thin sheet following impact the animal falls through the sheet onto a foam pad (I). Color image is available online.

approximately equal ratio- $57 \%$ used rats (SA 1.1 ), $43 \%$ used mice (SA 1.2), and two publications used both rats and mice (SA 1.3). In the $8 \%$ of publications that used female animals (SA 1.4), 17 of those articles used both males and females and only eight analyzed data by sex for sex differences (Fig. 4E; SA 1.5). Adult animals were the most common age reported (Fig. 4F; SA 1.7). At the young age range, $\mathrm{P} 7$ was a typical age used for mice, whereas P17-48 was common for rats (SA 1.6) (see online supplementary material). Only two publications specifically reported using aged mice, as defined by the authors of the publication (SA 1.8).

Weight drop model: model-specific common data elements. Our review of the model-specific common data elements for the weight drop method was informative for both the intermodel similarities, but also for the degree of variations that have been used. For $98 \%$ of the publications using the weight drop method, animals were anesthetized at the time of the impact, leaving six publications that did not use anesthesia (SA 1.9). The majority (72\%) of articles created an incision to expose the skull (SA 1.10). Of the publications that exposed the skull, metal disc helmet was placed on the skull in $40 \%$ of publications to diffuse the blow and reduce skull fractures and focal lesions (Figs. 3F and 4C; SA 1.11). The scalp was the surface of impact in $26 \%$ of articles (SA 1.12) (see online supplementary material), and a helmet on the scalp was used in $2 \%$ of articles (SA 1.13). There was an even split on the location of the injury, with $49 \%$ reporting a midline injury, 

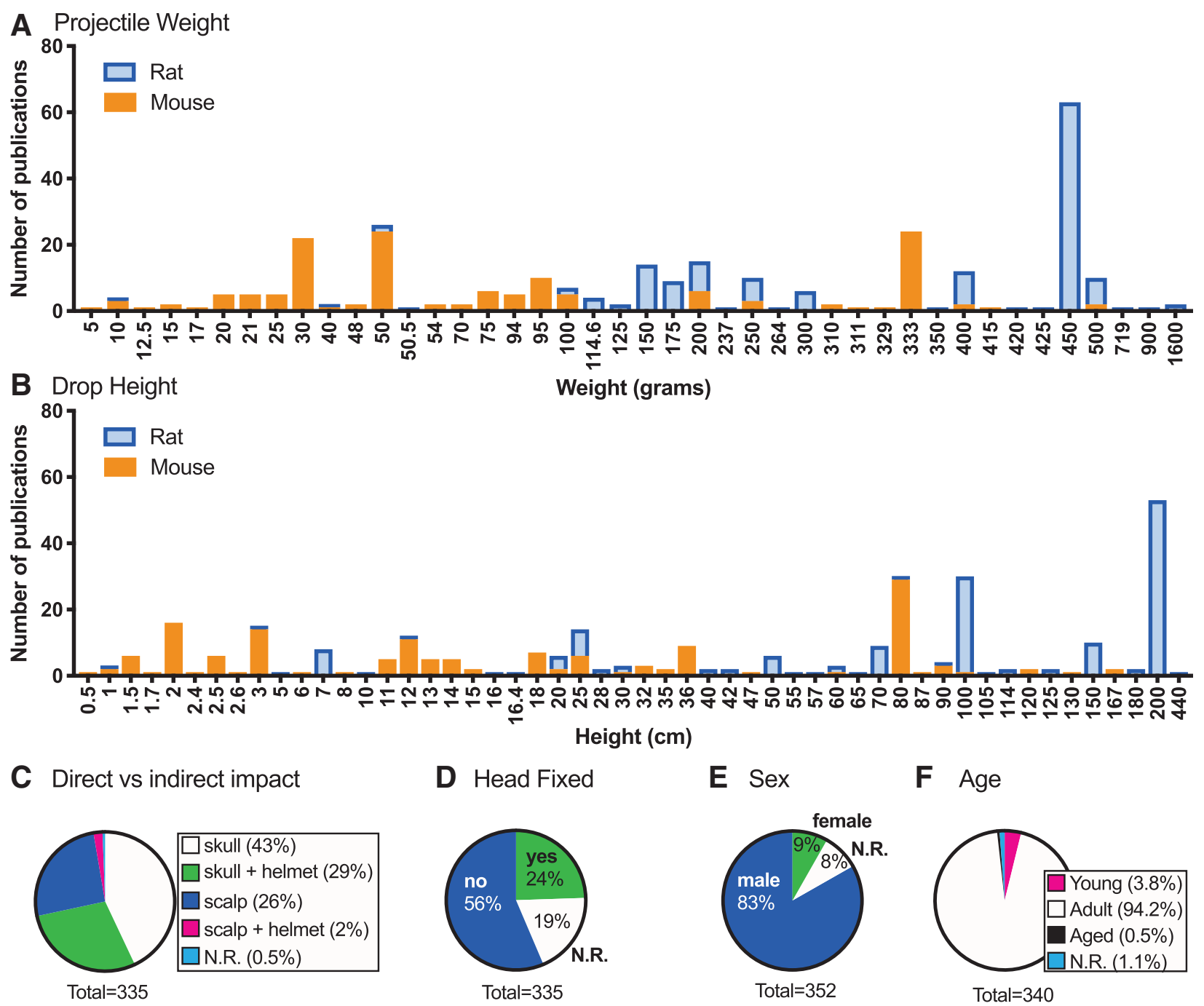

Weight (grams)

FIG. 4. Common data elements for the weight drop model. Weight drop models have been used with a variety of different weights (A) and heights (B). Mice were injured typically using lower weights and heights, while rats were injured using heavier weights and heights. Injuries were induced on different surfaces $(\mathbf{C})$ with the head either fixed or unfixed (D). A majority of papers used male (E), adult animals $(\mathbf{F})$. Total numbers for $(\mathrm{E})$ and $(\mathrm{F})$ are greater than the 335 total publications because several publications reported using more than one sex or age of animals. N.R., not reported. Color image is available online.

typically located in the midcoronal plane between bregma and lambda on the sagittal suture, and $48 \%$ reporting a lateral injury, typically located $1-2 \mathrm{~mm}$ lateral of midline in the midcoronal plane. In $56 \%$ of publications, the head was not secured and $19 \%$ of publications did not report this essential common data element (Fig. 4D). In $24 \%$ of publications, the head was held in place by methods that ranged from the heads being fixed rigidly with ear bars in a stereotactic frame (35\%; SA 1.14), loosely between two blocks $(6 \%$; SA 1.15$)$, or within the hand of the experimenter $(17 \%$; Fig. 3G; SA 1.16). (see online supplementary material). Similarly, $53 \%$ of publications did not report what the animal's head was resting on when it received the impact. Of those that reported resting surface of the head, a foam pad was used in $79 \%$ of publications (SA 1.17). We noted that few publications described the type and source of the foam pad, the spring constant of the foam, or how often it was replaced. Other surfaces that animals were placed on included, but were not limited to, foil (SA 1.18) see online supplementary material at (http://www.liebertpub.com), rubber
(SA 1.19), or spring-loaded platforms (SA 1.20). Fifty-three percent of weight drop publications did not specifically describe the surface that the animal rested on during injury induction.

The two major weight drop-specific common data elements where we observed significant variability was in the weight of the projectile, and the projectile drop height (Fig. 4A,B). The majority of publications that reported impactor material used a rigid projectile, which was most often a brass weight (75\%; Fig. 3I; SA 1.21 ). Whereas $25 \%$ of publications used a non-rigid projectile, which was most often a silicone tipped metal rod (SA 1.22), a few publications reported using a specific diameter projectile, but most did not report this common data element. Of the $57 \%$ of the total articles that used rats, the weight of the projectile used was most often $400 \mathrm{~g}$ or heavier (Fig. 4A). Also, projectiles were dropped from greater heights, on average, in the studies that used rats compared to experiments with mice (Fig. 4B). Seventy-six publications cited Marmarou and colleagues for the methods of the weight drop model. ${ }^{179}$ The investigators used a few variations on 
the name of the model (e.g., Marmarou, modified Marmarou, or impact-acceleration injury model), but most of the common data elements associated with the model were consistent. For instance, a 450 -g brass weight was dropped from a height of 200 or $100 \mathrm{~cm}$. The use of a 450-g weight with a $100-\mathrm{cm}$ height was reported in 13 publications (SA 1.23), whereas a $200-\mathrm{cm}$ drop height was reported in 44 publications (SA 1.24). Another aspect associated with these 57 publications was the use of a steel disk placed midline on the exposed skull as a "helmet." Animals were anesthetized and often intubated. The head was generally free to move, but was supported on a foam pad.

We found a cluster of publications in mice $(n=29)$ that used a drop height of $80 \mathrm{~cm}$ (SA 1.25). Of these 29 publications, $76 \%$ used a 30-g metal weight, commonly with a lateral impact (79\%). In these 29 articles, the impact was most often (83\%) to the scalp. A helmet was used in one publication. ${ }^{380}$ A second cluster of 32 reports ( $22 \%$ of mouse publications) used a drop height of $2.5 \mathrm{~cm}$ or less (SA 1.26). Of these 32 reports, $47 \%$ used a 333 -g projectile (SA 1.27), 75\% induced a lateral injury to one hemisphere of the brain (SA 1.28), and 88\% delivered the impact directly to the skull (SA 1.29). Most of these (23 of 32) articles were referencing Flierl and colleagues and/or Chen and colleagues for the methods. ${ }^{85,412}$

We also identified a few additional model-specific common data elements that were associated with either preventing rebound impacts or to cause a rotational injury. Specifically, some publications report methods to prevent rebound impacts from the projectile, including attaching a rope to the projectile (SA 1.30); however, a majority of the publications did not report this common data element. There are 12 publications of a modified version of the weight drop model where the animals are placed either on a Kimwipe or a piece of scored tin foil. Placement of the mice on the non-rigid material allows the animal to fall through the material and lands on a foam pad underneath from the force of the projectile impacting the head (Fig. 3H; SA 1.31).

Weight drop model: injury-induced functional and histopathological changes. In addition to the animal- and weight drop-specific common data elements, we also collected information about the previously assessed functional and histological endpoints in the model. We collected data for the presence or absence of an injury-induced change only. It was beyond the scope of this review to describe specifics of when the injury-induced changes occurred, if they resolved with time, and which endpoints showed the most significant injury effect. Our goal in summarizing the common endpoint measurements was to identify regularly reported endpoints that would be useful for comparisons between studies and highlight areas that are understudied.

Weight drop model: motor skills assays. The Neurological Scale Score (NSS) is a measurement used to test sensorimotor skills and involves a battery of tests. ${ }^{379}$ This test has been used and described for a mild ( $<10$ points), moderate (11-14 points), or severe injury ( $>14$ points) ${ }^{48}$ From our search, we found that of the 335 weight drop publications, only $31 \%$ reported doing the NSS. Of these articles, $87 \%$ reported a deficit and $13 \%$ reported no deficits after mTBI (SA 1.32). Further, righting reflex, a measure that is commonly used as a surrogate for loss of consciousness, ${ }^{5}$ was only reported in $10 \%$ of articles (SA 1.33). The most common latency for righting reflex was between 1 and $10 \mathrm{~min}$ (81\% of those who reported). Mortality rate was reported in $24 \%$ of publications. Low mortality $(0-5 \%)$ was found in $39 \%$ of these articles (SA 1.34), a moderate mortality (5-30\%) was found in $51 \%$ of articles (SA 1.35), and a high mortality rate $(30 \%+)$ was found in $10 \%$ of those articles who reported (SA 1.36).

An assessment of motor skills was most often done by one of three tests - balance beam, rotarod, and open field-and reported in $19 \%$ of weight drop publications (Fig. 5A). Specifically, the balance beam test was reported in $50 \%$ of publications with a deficit in $84 \%$ of those studies (SA 1.37). In the open field and rotarod assay, $67 \%$ (SA 1.38) (see online supplementary material) and $45 \%$ (SA 1.39) of the studies found a deficit, respectively. In addition to these three tests, nine additional motor skills tests were measured, including: foot placement (4/0), grid walking (1/0), grip test (3/1), tape removal (1/0), general activity $(2 / 1)$, staircase test $(0 / 1)$, whisker test $(2 / 0)$, seizure susceptibility $(1 / 0)$, and thermal or mechanical withdrawal $(1 / 0 ; n=$ deficit/no deficit; SA 1.40).

Weight drop model: learning and memory assays. Cognitive tasks typically involve learning in some capacity on the part of the animal, and common tests we found included passive avoidance, Y/T maze, radial arm water maze, novel object

\section{A Motor function}

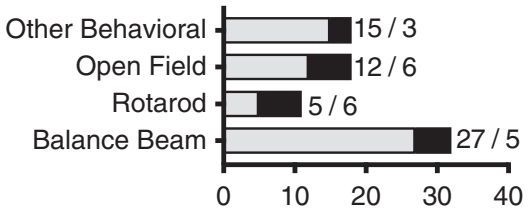

B Cognitive function

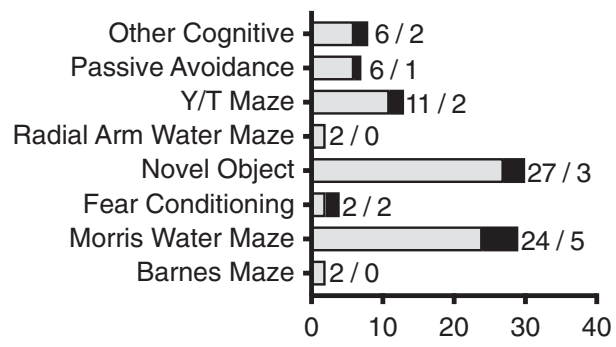

C Affective behavior function

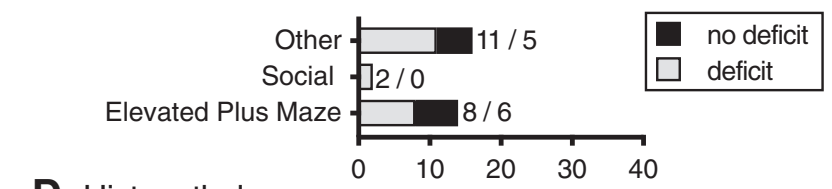

D Histopathology

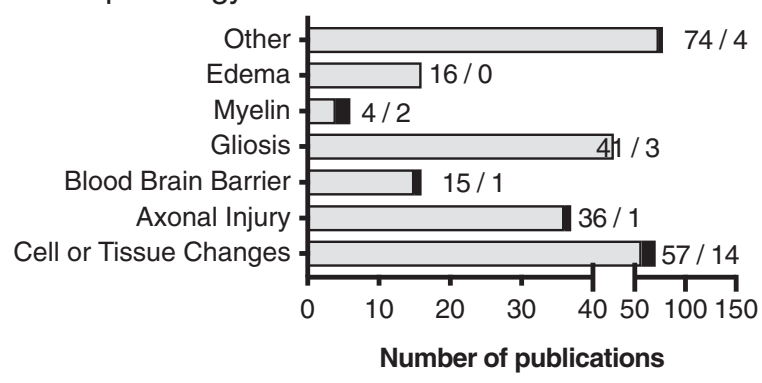

FIG. 5. Functional and Pathological deficits observed in the weight drop models of mTBI. Outcome measures collected included motor function (A), cognitive function (B), affective behaviors (C), and histology measures (D). Numbers indicate the number of studies with / without deficits. mTBI, mild traumatic brain injury. 
recognition, fear conditioning, Morris water maze, and Barnes maze. Twenty-one percent of weight drop articles reported doing some sort of cognitive testing. Of the articles reporting cognitive testing, deficits were recorded in $84 \%$ of cases (Fig. 5B). All of the publications that used either the Barnes maze or the radial arm water maze found deficits after mTBI (SA 1.41-42). In the Y/T maze (85\%; SA 1.43), novel object (90\%; SA 1.44) (see online supplementary material), and Morris water maze (83\%; SA 1.45), a majority of publications found a weight drop-induced deficits. When fear conditioning was tested, 50\% found deficits (SA 1.46). Passive avoidance was reported in two publications, and both found deficits (SA 1.47). Other cognitive testing identified, included the water finding test (2/2), location discrimination test (1/0), go/no-go testing (1/0), closed circle exiting (1/0), and novel context mismatch $(1 / 0 ; n=$ deficit/no deficit; SA 1.48).

Weight drop model: affective behavior testing. Affective behavior tests are designed to be used as a surrogate for more complex emotions like anxiety (and other affective behaviors). Of the 355 articles that used the weight drop method, only $7 \%$ reported affective behavior tests. The elevated plus or zero maze and social testing were commonly used in these publications (Fig. 5C). In the two publications that tested social behaviors, both found deficits compared to sham (SA 1.49). In the elevated plus maze tests, eight publications found deficits whereassix other publications did not find any deficits (SA 1.50). Other affective behavior tests that were reported included temperature sensitivity (1/0), tail suspension (1/2), olfactory avoidance (1/0), nociception (1/1), forced swim (6/1), fear conditioning (0/1), and acoustic startle reflexes (1/ $0 ; n=$ deficit/no deficit; SA 1.51).

Weight drop model: histopathology. In addition to behavioral tests, we collected information on which articles reported common histological changes that have been cited in the literature on brain injury. Cell or tissue changes are typically looked at by hematoxylin and eosin, cresyl violet, neuronal nuclei, or Nissl staining. Other categories of histological interest included axonal injury (shown by amyloid precursor protein, silver staining, or neurofilament stains), gliosis (shown by glial fibrillary acidic protein, ionized calcium binding adaptor molecule 1, CB68, or CD11b staining), myelin changes (shown by luxol fast blue or myelin basic protein staining), and blood-brain barrier disruption (Evans blue). Other staining was noted even if it was not within these categories.

Histology was more commonly reported as compared to behavioral changes in the articles included in our final analysis of weight drop models. Of the 335 articles, 55\% reported using histology of these major categories and, of those, $88 \%$ found there to be a significant change after mTBI compared to sham animals (Fig. 5D). Changes to cellular and tissue makeup were reported as significantly different from sham in $80 \%$ of publications whereas 14 publications did not find a deficit (SA 1.52). Deficits were also more common in axonal injury (95\%; SA 1.53); blood-brain barrier disruption (94\%; SA 1.54); edema (100\%; SA 1.55); gliosis $(93 \%$; SA 1.56); and myelin staining (67\%; SA 1.57). Many other histological measures were done for specific proteins of interest for the experimental design. A few of these include terminal deoxynucleotidyl transferase dUTP nick end labeling or apoptosis staining (11/1), inflammation/immune activation (10/0), caspase activation (3/0), complement activation (3/0), as well as many others (SA 1.58).

\section{Piston-driven closed head injury models}

Injuries caused by a piston are typically induced by zeroing the piston on the surface of the skull or scalp and then delivering an injury at a specific depth, velocity, or impact force (Fig. 3B). There are a few variations of the piston devices (Fig. 2B), including compressed nitrogen, electromagnetic, or pneumatically driven pistons (Fig. 3C,D). Another variation within this category is location of the injury and placement of the animal. For example, in the CHIMERA model, the animal is placed on its back within the device, and the injury is induced from below, thus allowing the head to flex after impact. ${ }^{202}$ Another example of using a piston at a different injury location is the "Hit \& Run" model. ${ }^{400}$ In order to induce an injury using this particular model, the animal is hung from a string by the incisors, allowing a piston to strike the side of the head. This approach allows the animal to freely move after the impact. Other models use lateral angle for impact; however, in these models, animals lie on a flat surface and move laterally after the impact ${ }^{106,199,236}$ (Fig. 3E).

As in the weight drop articles, we also collected animal indicators such as 1) species, 2) sex (Fig. 6A), and 3) age (Fig. 6B). Common data elements of the injury were collected for these piston-driven models as well. We recorded 1) anesthesia use; 2) surgery indication; 3) head fixation (Figs. 3G and 6C); 4) method of head fixation; 5) impact location; 6) impact surface (Figs. 3F and 6D); 7) what material the animal was placed on; 8) impactor tip size (Fig. 6E) and shape; 9) impact velocity (Fig. 6F); and 10) head displacement (Fig. 6G).

Piston-driven closed head injury models: animal-specific common data elements. Most articles using piston-driven injury utilized mice (74\%) as opposed to rats (26\%; SA 2.1). Of the articles that reported the sex of the animals, males (72\%) were most common (Fig. 6A; SA 2.2). When females were used, 94\% of the articles also included males; and only half of the time were data separated by sex to determine sex differences (SA 2.3). Adult animals were most prevalent (79\%), followed by pups (19\%; SA 2.4), with no studies reporting the use of aged animals (Fig. 6B).

Piston-driven closed head injury models: model-specific common data elements. Anesthesia was uniformly used for this injury model. Direct impacts were given either to the scalp (17\%; SA 2.5) or exposed skull (49\%; Fig. 6D; SA 2.6) (see online supplementary material). A helmet was used in $35 \%$ of articles, either placed on the scalp (SA 2.7) or skull (SA 2.8). The head was left free to move after the injury in $33 \%$ of the publications (Fig. 6C; SA 2.9), and in some cases the animal was placed on a foam pad (SA 2.10) or on scored tin foil and allowed to fall through the foil after the injury (Fig. 3H; SA 2.11). Generally, if an animal's head was fixed, a stereotactic frame was used $(77 \%$; Fig. 3G; SA 2.12). Other methods of securing the head varied in the amount that the head was able to move after injury; this included foam wrapped ear bars, ${ }^{355}$ an acrylic or resin mold, ${ }^{347,363}$ a plastic collar, ${ }^{348}$ a mouse restrainer, ${ }^{349}$ or secured vertically from the incisors. $^{400}$

Velocity of the impact used in mice was typically slower as compared to rats (Fig. 6F). Six publications used an impact velocity of $6.8 \mathrm{~m} / \mathrm{s}$, the fastest velocity used in mice (SA 2.13). All six cited the previous works by Lynch and colleagues. ${ }^{365,366}$ With this model, a rigid, flat impact tip of $2 \mathrm{~mm}$ was typically used (Fig. 6E). An impact of $5 \mathrm{~m} / \mathrm{s}$ was reported in seven publications in mice with a 5-mm impact tip and impacted either 1 or $1.5 \mathrm{~mm}$ deep (SA 2.13). 
A

A Sex

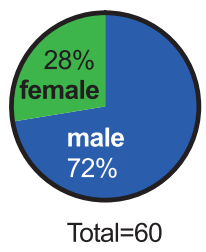

Head fixation

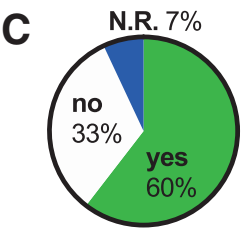

Total $=43$

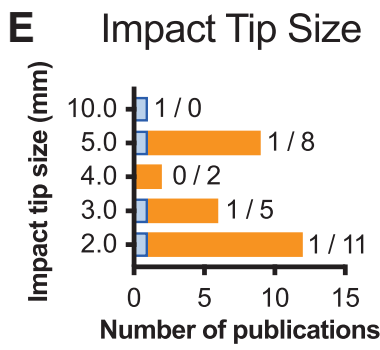

F Impact Velocity

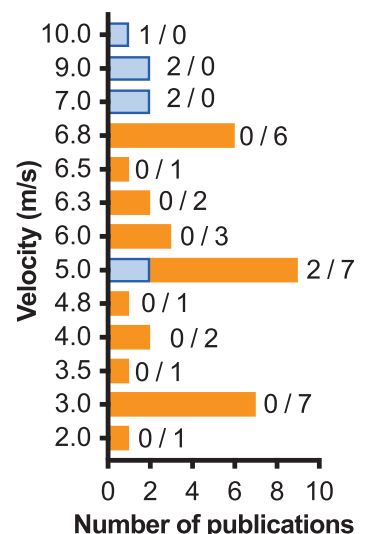

FIG. 6. Piston driven CHI models of mTBI common data elements. Most animals were male (A) and adult (B). The head was most often fixed $(\mathbf{C})$ and the impact surface varied (D). The impact tip size when reported was typically $5 \mathrm{~mm}$ or less $(\mathbf{E})$. Impact velocity (F) and depth $(\mathbf{G})$ were smaller for mice than rats. Numbers indicate the number of studies using rats / mice. Total numbers are greater than the 43 total publications because several publications reported using more than one sex or age. CHI, closed head injury; N.R., not reported. Color image is available online.

A common reference was not used for this configuration. Publications using rats $(n=11)$ reported using faster velocities of ranging from 5 to $10 \mathrm{~m} / \mathrm{s}$ (SA 2.14).

The depth of impact set on the piston device was also typically smaller for mice than rats (Fig. 6G). One head displacement depth of $10 \mathrm{~mm}$ was used in the Hit \& Run model. ${ }^{400}$ All other reported head displacement depths were $3.2 \mathrm{~mm}$ or less (SA 2.15).
Different materials could be used within the impactor tip, with $58 \%$ using a rigid tip and 5\% reporting a flexible tip such as rubber or silicone (Fig. 3I; SA 2.16). A large number of publications did not report the material of the impact tip (37\%; SA 2.17). The shape of the impact tip was most often flat $(60 \%)$ or round $(35 \%)$ when reported (SA 2.18).

Piston-driven closed head injury model: injury-induced functional changes. We found for the piston-driven model that mortality was under-reported (only $23 \%$ of articles reporting), with most (90\%) reporting a mortality rate of $0-5 \%$ (SA 2.19). Moderate mortality was reported in one publication, and no publications reported high mortality (SA 2.19). Righting reflex was reported in $33 \%$ of the piston-driven closed head injury (CHI) models, with most having a latency of $1-10 \mathrm{~min}(79 \%$; SA 2.20$)$.

Piston-driven closed head injury model: motor skills assays. The NSS was not commonly reported in the piston-driven CHI model, with only one publication reporting no deficit ${ }^{365}$ and two finding a significant change from sham after injury. ${ }^{202,354}$ Deficits were found in five publications after piston-driven injury in the balance beam, with one publication finding no deficits (SA 2.21). Rotarod was tested in 10 publications, and nine found deficits with one publication finding no change after injury (SA 2.22). Open field was tested in six publications, and in five, deficits after mTBI were found and one found no deficit (SA 2.23). Other motor tests assessed in the piston-driven CHI included wheel running and wire hanging, with deficits observed in both assays (Fig. 7A; SA 2.24).

Piston-driven closed head injury model: learning and memory assays. Forty-seven percent of piston-driven CHI publications reported cognitive testing. The Morris water maze was the most commonly used cognitive test after the piston-driven $\mathrm{CHI}$, and deficits were commonly found (88\%; SA 2.25). All three of the publications using fear conditioning after a piston-driven $\mathrm{CHI}$ reported an injury-induced deficit, whereas two of three publications using novel object recognition found an injury-induced deficit (SA 2.26). The Y/T maze (2/0), radial arm water maze (1/1), and Barnes maze (1/1) were each run in two publications ( $n=$ deficit/no deficit; SA 2.26). The passive avoidance test with no deficit and a labyrinth maze test with a deficit were reported only once (Fig. 7B; SA 2.26).

Piston-driven closed head injury model: affective behavior testing. Affective behavior changes in different affective behaviors were reported in $19 \%$ of the piston-driven models $(n=8)$. When these tests were conducted, three of four found deficits in the elevated plus maze (3/1; SA 2.27) and two of three found social deficits (Fig. 7C; SA 2.28). One other affective behavior test was conducted in this group, a sucrose preference task, in which a deficit was found after injury. ${ }^{385}$

Piston-driven closed head injury model: histopathology. Histopathology was reported in $74 \%$ of the pistondriven $\mathrm{CHI}$ publications we reviewed. Cell or tissue changes were reported in 9 of 10 publications (SA 2.29). Axonal injury was reported in 13 of 14 publications (SA 2.30). Gliosis was reported in 19 of 19 publications (SA 2.31). Three publications reported injuryinduced alterations in myelin (SA 2.32). The other histopathological endpoints that we noted included blood-brain barrier alterations (1/ 
A Motor function

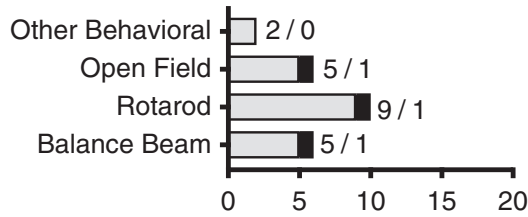

\section{B Cognitive function}

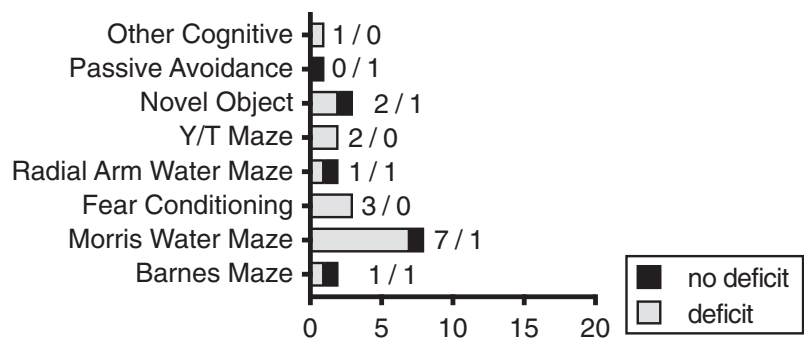

C Affective behavior function
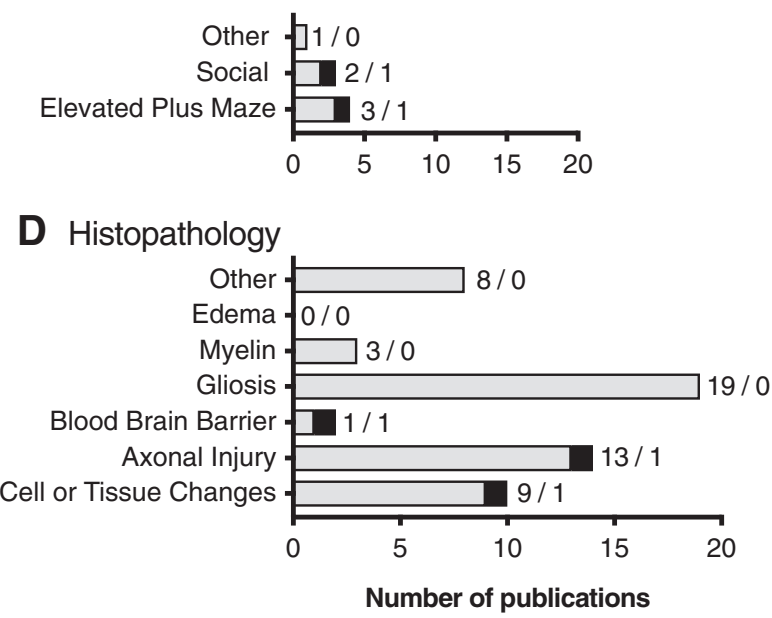

FIG. 7. Outcome measures for piston driven injury models. Common tests typically reported for motor function (A), cognitive function (B), affective behaviors (C), and histological measures (D) were reported. Numbers indicate the number of studies with / without deficits.

1), inflammation (2/0), caspase activation (1/0), and complement activation (1/0; $n=$ deficit/no deficit; Fig. 7D; SA 2.33).

\section{"Other" models}

The last broad class of mTBI models we defined as "other" models. We organized these models based on the biomechanical mechanism or type of device used to cause the injury. As shown in Figure 2C, the most commonly used of these "other" models was the rotational injury models (SA 3.1), whereas the least widely used was the reflex hammer model. ${ }^{390}$ Although some of these models date back to the 1940s, it is still important to consider these older and less-used methods given that these studies are informative on how mild TBIs have been modeled over time. Our review of these models, which follows, will go from the most to the least used (Fig. 2C).

The group of "other" models with the most publications are associated with a rotational biomechanical mechanism. Two models have been developed that utilized rotation to induce mTBI.
The Medical College of Wisconsin Rotational Injury model (SA 3.1) produced an injury by using a spring-loaded launching arm that strikes a moment arm. This moment arm causes the device to rotate with the animal's head in it, thus causing the injury. The head is fixed after induction of anesthesia, and no incision is made to the scalp. In a similar model, Rostami and colleagues induced a rotational injury in anesthetized rats by placing the animal with an exposed skull in the injury device and hitting a bar within the device to cause rotation of the animal's head (SA 3.1). Of the rotational injury models, two publications used females, ${ }^{278,409}$ whereas four used males. ${ }^{375,388,389,401}$ All six publications used adult rats. When reported, both models resulted in low mortality when reported. ${ }^{278,388}$ with long righting reflex latencies of over 10 min. ${ }^{388,389}$ NSS was performed in one publication, and no deficits were found after injury. 409

Spring-loaded injury devices-used pre-1990s — are another method used to induce mTBI. One of these models uses a modified rat trap to induce injury. ${ }^{247,406,407}$ No anesthesia was used in this model, and the injury was induced onto the intact scalp of the rat. The injury used the spring-loaded rat trap with a modified knob on the end to hit the midline of the adult male rat head. Mortality with this model was reported in one publication between $0 \%$ and $5 \%$ and in another 5-30\%, ${ }^{247}$ and when a righting reflex was reported, it was between 1 and $10 \mathrm{~min}^{247}$ Another model used a coiled springloaded gun to induce mTBI. ${ }^{210}$ With this model, a helmet was secured to the skull of the adult male rats. Mortality in this model was $5-30 \%$, with a righting reflex of $1-10 \mathrm{~min}$.

Fall-type injury models have the animals fall onto an immovable surface. ${ }^{378,392,413}$ The authors of these models speculate that this model may more closely mimic certain head trauma cases in humans with the head moving and hitting a stationary object. ${ }^{413}$ These injuries were induced both with and without anesthesia, but always to the scalp. The injury was induced when the animal's head (midline) hit the stationary object at the bottom of the fall. Male $(n=2)^{392,413}$ and female $(n=1)^{413}$ adult rats were used with these models. Mortality and NSS were not reported with this model. Righting reflex $1-10$ min was reported in two publications. ${ }^{392,413}$

A pendulum injury model is another older model used to induce mTBI. ${ }^{238,394,398}$ In all of these publications, the animals were anesthetized. One publication did not fix the head ${ }^{394}$ whereas the other two used a bite bar to secure the head. ${ }^{238,398}$ All injuries were to the scalp of rats, and only adult males were used. No mortality rates were reported, and when a righting reflex was reported, the latency was $1-10 \mathrm{~min} .{ }^{394} \mathrm{NSS}$ was reported with deficits after mTBI in one publication. ${ }^{398}$

Two models were developed that we defined as projectile models. The Walter Reed Army Institute of Research developed a model called the WRAIR Projectile Concussive Impact model. ${ }^{387,395}$ In this model, anesthetized animals are placed on their back on a movable platform above a heating unit. Within the heating unit, they place a microcentrifuge tube filled with dry ice with a secure cap, causing the ice to sublimate, and the pressure causes the cap to be shot off and hit the helmet from below. ${ }^{387}$ The head is not fixed, but the body of the animal is held in place with an elastic band. This model used adult, male rats that were anesthetized and impacted laterally on the intact skull with a helmet. One other model from 1984 used a projectile to induce mTBI in adult male rats. ${ }^{405}$ In this model, a dart was shot at midline of the exposed scalp of an anesthetized animal. Mortality rates and the NSS were not reported for these models. Only one publication reported a righting reflex latency of $1-10 \mathrm{~min}^{395}$ 
MicroTBI is a unique surgical technique used to cause increased pressure to the surface of the brain. ${ }^{159,227,397}$ This technique first surgically thins the skull of the mice and then applies pressure for a certain period to cause a brain injury. The head is fixed within a stereotactic frame through the injury procedure. Animals are anesthetized, the injury is caused laterally on the left somatosensory cortex of adult male mice. Mortality, righting reflex, and the NSS were not reported with this model.

The Maryland model of mTBI uses the energy of steel ball rolling down a 2.1-m track, hitting a coupling device that causes the impact to be centered on the malar processes to impact the front of the head. ${ }^{391,393}$ Rats are anesthetized and taped in place to reduce movement. The skull is not exposed in this model; however, surgery is done in order to expose the malar processes in which the injury device is positioned. The head is fixed in place within the device and is not free to move after the impact. Both publications with this model used adult male rats. One publication reported a mortality rate of $0-5 \%,{ }^{393}$ and the other reported no deficit in the NSS. ${ }^{391}$ Righting reflex was not reported for this model.

Finally, one model from 1997 used a rubber reflex hammer that is fixed to a pivot for injury production. ${ }^{390}$ This injury was induced onto the intact scalp of adult of anesthetized adult male rats. Mortality, righting reflex, and the NSS were not reported with this model.

"Other" model: model and animal-specific common data elements. In this group as a whole, anesthesia was used in $80 \%$ of publications (Fig. 8A; SA 3.2), and the head was fixed in $84 \%$ of publications (SA 3.3). Different impact locations were used; $24 \%$ scalp with a helmet; $12 \%$ on the skull with a helmet; $44 \%$ to the intact scalp; and $20 \%$ to the skull (Fig. 8B; SA 3.4-3.7). Rats were used in $88 \%$ of publications (Fig. 8C; SA 3.8). A majority of the publications (76\%) used male animals, regardless of species (Fig. 8D; SA 3.9). Of the publications that used females, one used both males and females and they did look at sex differences in their outcomes. ${ }^{413}$ All of these publications used adult animals.

"Other" model: injury-induced functional and histopathological changes. Behavioral outcomes were collected for these models as well. Motor behaviors were reported in $28 \%$ of these "other" models. The balance beam test commonly found deficits (3/2) ( $n=$ deficit/no deficit), and in one publication in the open field test (Fig. 8E; SA3.10). Rotarod was tested in one publication, and no deficits were found (SA 3.11). Other behavioral tests conducted included incline plane (1/0), gait analysis $(1 / 0)$, and vision changes $(1 / 0 ; n=$ deficit/no deficit; SA 3.12). Cognitive outcomes were reported in $24 \%$ of these publications (Fig. 8F). Testing in the main measurements was only observed for the Morris water maze (0/4), the radial arm maze (1/0), and novel object recognition $(1 / 0$; $n=$ deficit/no deficit; SA 3.13). No other cognitive testing was reported in any of these "other" models. Of the common affective behavior tests, only the elevated plus maze was reported (2/1; $n=$ deficit/no deficit; Fig. 8G; SA 3.14).

Histology, much more common in this category as compared to behavioral testing, was reported in $52 \%$ of publications (Fig. $8 \mathrm{H}$ ). Cell and tissue changes were found in six publications, with one publication finding no deficits (SA 3.15). Similarly, axonal injury histological marker deficits were found in five publications, with two finding no deficits (SA 3.16). Gliosis activation was tested in five publications, and four found deficits while one found none
A Anesthesia Use

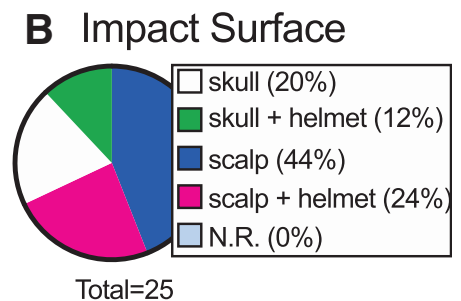

C Sex

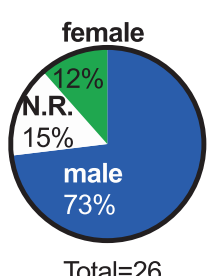

Total $=26$
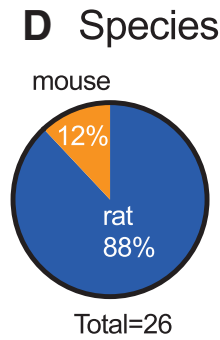

E Motor function

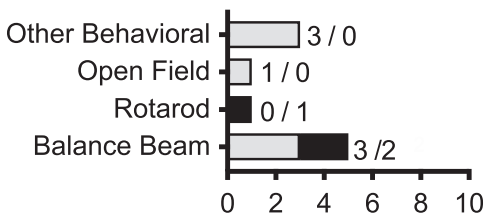

F Cognitive function

$$
\begin{aligned}
& \text { Other Cognitive } 10 \text { / } 0 \\
& \text { Passive Avoidance } 0 \text { / } 0 \\
& \text { Novel Object } \square 1 / 0 \\
& \text { Y/T Maze - } 0 / 0 \\
& \text { Radial Arm Water Maze } \square \text { 1/0 } \\
& \text { Fear Conditioning }-0 / 0 \\
& \text { Morris Water Maze } 0 / 4 \\
& \text { Barnes Maze } \\
& \begin{array}{llllll}
\hline \multicolumn{2}{|l|}{0 / 0} & & & & \\
\hline 0 & 2 & 4 & 6 & 8 & 10
\end{array}
\end{aligned}
$$

G Affective behavior function

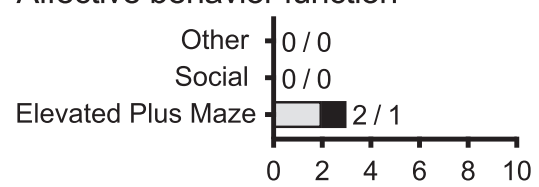

H Histopathology

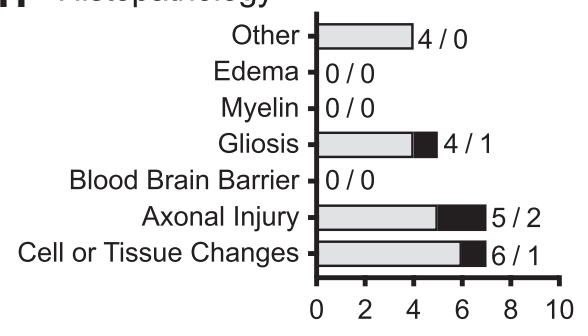

Number of publications

FIG. 8. "Other" models common data elements. Most publications used anesthesia (A). Impact locations varied between models (B). However, most publications used males (C), and rats (D). Motor function $(\mathbf{E})$, cognitive function $(\mathbf{F})$, affective behaviors $(\mathbf{G})$, and histological changes $(\mathbf{H})$ were recorded for all "other" models. Numbers indicate the number of studies with / without deficits. Total numbers are greater than the 25 total publications in (C) and (D) because several publications reported using more than one sex and species. N.R., not reported. Color image is available online. 
(SA 3.17). Other histology included complement activation (1/0), doublecortin (1/0), brain-derived neurotrophic factor $(1 / 0)$, and aquaporin $4(1 / 0 ; n=$ deficit/no deficit; SA 3.18) (see online supplementary material).

\section{Discussion}

In this systematic review, we identified and screened 1890 publications and summarized 402 original scientific reports of rodent $\mathrm{CHI}$ models of mTBI. We provide a summary of the common data elements used in these mTBI models to help define the current state of the field of rodent pre-clinical mTBI models. Identifying the common data elements is essential for big data efforts, such as the Federal Interagency Traumatic Brain Injury Research (FITBIR) informatics system (fitbir.nih.gov). We believe that our review will provide a framework for future research by summarizing the similarities and differences between models of CHI for mTBI, in both the ways the models were conducted and major classes of outcomes that were measured. Moreover, this review highlights the need for a consensus agreement on the best practices for pre-clinical models of mTBI CHI to both help new investigators move into the field and provide some degree of standardization of the common data elements used across laboratories. In addition to our review of the common data elements and outcome variables, excellent past reviews have discussed the TBI models of all severity types and comprehensively looked specifically at strengths and weaknesses of the different TBI models. We recommend that the interested reader consider the following reviews. ${ }^{5,414-422}$

In comparison to pre-clinical models of moderate-to-severe TBI, the number of publications attempting to model mild TBI is much smaller in number. At the same time, there is currently increased excitement in the field for developing mTBI models, in part because of the alarming number of people that suffer a mTBI, and the appreciation that an mTBI can have a lasting negative impact on the health of the brain. As new models are developed and characterized, they will add significantly to our understanding of the natural history of mTBI and how different biomechanical forces alter that history. Our review will help place emerging data into a historical context. By comparing how the values of injury model common data elements vary, and thus result in similar or disparate outcomes, can help to identify the most important aspects of the model that are leading to increased variability or are critical for causing a particular histopathological or functional outcome.

Before the early 1980s, there were no commercially available experimental models of TBI, which accounts for many of the "other", models found from our search criteria (Fig. 2D). Further, during this time period, many researchers were using cats and dogs to study $\mathrm{TBI}^{423}$ and therefore would have been excluded from this review that pertains specifically to rodent models: a potential limitation of our review.

In 1989, a model was produced and marketed by General Motors Research Laboratory that changed the trajectory of TBI research. ${ }^{414}$ The production of this piston-driven model was the early precursor to the CCI model-described initially in ferrets and later adapted for use in rodents. ${ }^{424}$ We mention the General Motors model here because of its contribution to commercially available models. In 2007, the Impact One ${ }^{\mathrm{TM}}$ was introduced to the market as a cheaper, user-friendly, and more space economical version of a piston impactor, which again changed the trajectory of TBI research. ${ }^{425}$ Introduced by Marmarou and colleagues in $1994,{ }^{179}$ the weight drop model was another major advancement in the field of
$\mathrm{CHI}$, given that the device itself was easily producible in individual labs and continues to be widely used in the TBI field.

The presence of many different models can be a strength given that the differences between each one provides an opportunity to study varying mechanics of injury. We recognized that common data elements, which we currently view as important, were left out of many publications. For example, weight drop publications often did not include all details about the foam used to support the animals. It is known that specific foams can be used a finite number of times with a specific amount of time between use before the mechanical properties change. ${ }^{426}$ Thus, the understanding of the mechanical properties of the foam are important to report for future studies to ensure reproducibility. Similarly, within the pistondriven models, not all articles reported the impactor tip shape. In the CCI model, use of a flat or a rounded impact tip was found to change the progression and severity of the injury ${ }^{427}$; thus, the shape of the impact tip is important to know for understanding the injury produced. Although the surface of the brain is not exposed for the injury models in this review, it is reasonable to assume that the same principle will apply to CHIs. We mention these examples not to suggest that publications we reviewed which failed to report foam properties or impactor tip shape are flawed studies. For many of these studies, it was unknown at the time that foam properties or impactor tip shape were important. Nevertheless, having welldefined reporting standards for future studies will improve our ability to make cross-study comparisons. Along with ongoing efforts such as FITBIR, which will define national common data element reporting standards, this review will also help in providing context to the standards.

\section{Future directions}

A striking finding from this work is the general lack of female animals used in mTBI models. This creates a huge gap in the understanding of brain injury responses specific to females. In 2000, a meta-analysis was conducted on clinical TBI studies which indicated poorer outcomes for females after a TBI. ${ }^{428}$ Differences between sex hold true also with pre-clinical animal model TBI. ${ }^{429}$ Many studies are not statistically powered to analyze the data by sex, given that the effect of sex may not be a specific aspect of their hypothesis. Nevertheless, for studies that include both male and female animals, future big data efforts of merging studies to look for effects of sex will only be possible if more researchers include both sexes in their studies.

Another major gap identified by this systematic review is the lack of both models of pediatric and geriatric mTBI. The CDC indicates that the rates of mTBI are at least several times higher in children compared to adults. ${ }^{1}$ Further, higher rates of mTBI are noted in the geriatric population ( $>65$ years of age) compared to adults. ${ }^{3}$ Future studies addressing similarities and dissimilarities between adult animals and animals at the opposite ends of the aging spectrum will be useful to understand what aspects, if any, of the adult preclinical mTBI models are relevant to these two most atrisk patient populations.

Of the various dependent variables measured and collected in our review, we also collected the time point at which each publication looked at their variable. From this information, we found that very few of the 403 publications looked further than 1 month after mTBI. With the CDC reporting that around 5.3 million individuals live with a permanent TBI-related disability, the lack of longterm studies in the literature is a major gap that needs to be filled in the field. ${ }^{1}$ 


\section{Limitations}

Not only within the context of this review, but in the TBI field as a whole, the definition of mTBI can vary from study to study. Most often, mTBI and concussion are used interchangeably. Experts have attempted to establish universal guidelines, but they have only been able to agree on the fact that mTBI represents a "change in brain activity from a traumatic force." 3 Changes in brain function can be so subtle that they may be difficult to detect, as observed in some of the publications included in this review in which no deficits in behavior or histological measures could be found after a traumatic blow to the head of a rodent. While we attempted to only include publications that were mild, we relied on the author's criteria for a mild injury, which can be rather varied.

The guideline for systematic reviews published by PRISMA includes a section to address bias within and between the articles used for the review. ${ }^{7} \mathrm{We}$ did not address the quality of the publications included in the final analysis. The aim of this review was to compile a list of closed head mTBI rodent models and simply provide which tests have been done within those publications. Future work may use the models found from this review and retrieve information from the publications about the time course of pathology or behavior changes noted and compare across studies.

When outcome measures were recorded from the 402 publications, certain tests, such as the open field and the passive avoidance test, were kept within one category, either motor or cognitive respectively. These tests have multiple aspects, however, that can measure different parts of rather complex behaviors. Further investigation to determine which factor was the main purpose of the test for each article's experimental design is warranted.

\section{Conclusion}

We have compiled over 400 articles all using a closed head mild injury model to study TBI in rodents. Not only are all of these articles now in one place, but further information about the common data elements of the injury protocol, the animals used, and the outcomes measured have also been compiled and summarized. We believe that this review will be helpful for understanding where the closed head mTBI field has been, where gaps are present that need to be addressed, and what the future holds for the field.

\section{Acknowledgments}

C.N.B. was supported, in part, by a Kentucky Spinal and Head Injury Trust trainee fellowship. Research reported in this publication was supported by the National Institutes of Health under award numbers R00 AG044445 (to A.D.B.) and P30 GM110787 (to A.D.B.). The content is solely the responsibility of the authors and does not represent the official views of the funding organizations.

\section{Supplementary Material}

Supplementary Appendix

\section{Author Disclosure Statement}

No competing financial interests exist.

\section{References}

1. Centers for Disease Control and Prevention, National Center for Injury Prevention and Control. (2003). Report to Congress on Mild Traumatic Brain Injury in the United States: Steps to Prevent a Serious Public Health Problem. CDC: Atlanta, GA.
2. McKee, A.C., and Daneshvar, D.H. (2015). The neuropathology of traumatic brain injury. Handb. Clin. Neurol. 127, 45-66.

3. Voss, J.D., Connolly, J., Schwab, K.A., and Scher, A.I. (2015). Update on the epidemiology of concussion/mild traumatic brain injury. Curr. Pain Headache Rep. 19, 32.

4. Coronado, V.G., Haileyesus, T., Cheng, T.A., Bell, J.M., HaarbauerKrupa, J., Lionbarger, M.R., Flores-Herrera, J., McGuire, L.C., and Gilchrist, J. (2015). Trends in sports- and recreation-related traumatic brain injuries treated in US emergency departments: the National Electronic Injury Surveillance System-All Injury Program (NEISSAIP) 2001-2012. J. Head Trauma Rehabil. 30, 185-197.

5. DeWitt, D.S., Perez-Polo, R., Hulsebosch, C.E., Dash, P.K., and Robertson, C.S. (2013). Challenges in the development of rodent models of mild traumatic brain injury. J. Neurotrauma 30, 688-701.

6. Nokkari, A., Mouhieddine, T.H., Itani, M.M., Abou-Kheir, W., Daoud, G., Zhu, R., Mechref, Y., Soueid, J., Al Hariri, M., Mondello, S., Jaffa, A.A., and Kobeissy, F. (2015). Characterization of the Kallikrein-Kinin system post chemical neuronal injury: an in vitro biochemical and neuroproteomics assessment. PLoS One 10, e0128601.

7. Moher, D., Liberati, A., Tetzlaff, J., and Altman, D.G.; PRISMA Group. (2009). Preferred reporting items for systematic reviews and meta-analyses: the PRISMA statement. PLoS Med. 6, e1000097.

8. Courtney, A., and Courtney, M. (2015). The complexity of biomechanics causing primary blast-induced traumatic brain injury: a review of potential mechanisms. Front. Neurol. 6, 221.

9. Abookasis, D., Shochat, A., and Mathews, M.S. (2013). Monitoring hemodynamic and morphologic responses to closed head injury in a mouse model using orthogonal diffuse near-infrared light reflectance spectroscopy. J. Biomed. Opt. 18, 045003.

10. Abookasis, D., Volkov, B., and Mathews, M.S. (2013). Closed head injury-induced changes in brain pathophysiology assessed with nearinfrared structured illumination in a mouse model. J. Biomed. Opt. $18,116007$.

11. Adeleye, A., Shohami, E., Nachman, D., Alexandrovich, A., Trembovler, V., Yaka, R., Shoshan, Y., Dhawan, J., and Biegon, A. (2010). D-Cycloserine improves functional outcome after traumatic brain injury with wide therapeutic window. Eur. J. Pharmacol. 629, 25-30.

12. Adelson, P.D., Jenkins, L.W., Hamilton, R.L., Robichaud, P., Tran, M.P., and Kochanek, P.M. (2001). Histopathologic response of the immature rat to diffuse traumatic brain injury. J. Neurotrauma 18, 967-976.

13. Al-Samsam, R.H., Alessandri, B., and Bullock, R. (2000). Extracellular N-acetyl-aspartate as a biochemical marker of the severity of neuronal damage following experimental acute traumatic brain injury. J. Neurotrauma 17, 31-39.

14. Albert-Weissenberger, C., Stetter, C., Meuth, S.G., Gobel, K., Bader, M., Siren, A.L., and Kleinschnitz, C. (2012). Blocking of bradykinin receptor B1 protects from focal closed head injury in mice by reducing axonal damage and astroglia activation. J. Cereb. Blood Flow Metab. 32, 1747-1756.

15. Ali, A., Konakondla, S., Zwagerman, N.T., Peng, C.Y., Schafer, S., Ding, J.Y., Dornbos, D., Sikharam, C., Geng, X.K., Guthikonda, M., Kreipke, C.W., Rafols, J.A., and Ding, Y.C. (2012). Glycerol accumulation in edema formation following diffuse traumatic brain injury. Neurol. Res. 34, 462-468.

16. Allitt, B.J., Johnstone, V.P.A., Richards, K., Yan, E.B., and Rajan, R. (2016). Progesterone exacerbates short-term effects of traumatic brain injury on supragranular responses in sensory cortex and overexcites infragranular responses in the long term. J. Neurotrauma 33, 375-389.

17. Arakawa, S., Nakamura, S., Kawashima, N., Nishiike, S., and Okuyama, S. (1995). Antagonizing effects of VA-045 on reduced activity of rat locus coeruleus neurons following head injury or intravenous injection of clonidine. Life Sci. 57, 1803-1810.

18. Arican, N., Kaya, M., Yorulmaz, C., Kalayci, R., Ince, H., Kucuk, M., Fincanci, S.K., and Elmas, I. (2006). Effect of hypothermia on blood-brain barrier permeability following traumatic brain injury in chronically ethanol-treated rats. Int. J. Neurosci. 116, 1249-1261.

19. Arien-Zakay, H., Gincberg, G., Nagler, A., Cohen, G., LirazZaltsman, S., Trembovler, V., Alexandrovich, A.G., Matok, I., Galski, H., Elchalal, U., Lelkes, P.I., Lazarovici, P., and Shohami, E. (2014). Neurotherapeutic effect of cord blood derived CD45(+) hematopoietic cells in mice after traumatic brain injury. J. Neurotrauma $31,1405-1416$. 
20. Asa, I., Ivashkova, Y., Artru, A.A., Lifshitz, M., Gavrilov, V., Azab, A.N., Kapuler, V., Alouchin, A., Rachinsky, M., Pruneau, D., Shapira, Y., and Kaplanski, J. (2003). LF 16-0687 Ms, a new bradykinin B2 receptor antagonist, improves neurologic outcome but not brain tissue prostaglandin E2 release in a rat model of closed head trauma combined with ethanol intoxication. J. Trauma 54, 881-887.

21. Atalay, B., Caner, H., Can, A., and Cekinmez, M. (2007). Attenuation of microtubule associated protein-2 degradation after mild head injury by mexiletine and calpain-2 inhibitor. Br. J. Neurosurg. 21, 281-287.

22. Badeli, H., Shahrokhi, N., KhoshNazar, M., Asadi-Shekaari, M., Shabani, M., Vaghefi, H.E., Khaksari, M., and Basiri, M. (2016). Aqueous date fruit efficiency as preventing traumatic brain deterioration and improving pathological parameters after traumatic brain injury in male rats. Cell J. 18, 416-424.

23. Baky, N.A.A., Fadda, L., Al-Rasheed, N.M., Al-Rasheed, N.M., Mohamed, A., and Yacoub, H. (2016). Neuroprotective effect of carnosine and cyclosporine-A against inflammation, apoptosis, and oxidative brain damage after closed head injury in immature rats. Toxicol. Mech. Methods 26, 1-10.

24. Baratz-Goldstein, R., Deselms, H., Heim, L.R., Khomski, L., Hoffer, B.J., Atlas, D., and Pick, C.G. (2016). Thioredoxin-mimetic-peptides protect cognitive function after mild traumatic brain injury (mTBI). PLos One 11, e0157064.

25. Baratz-Goldstein, R., Toussia-Cohen, S., Elpaz, A., Rubovitch, V., and Pick, C.G. (2017). Immediate and delayed hyperbaric oxygen therapy as a neuroprotective treatment for traumatic brain injury in mice. Mol. Cell. Neurosci. 83, 74-82.

26. Baratz, R., Rubovitch, V., Frenk, H., and Pick, C.G. (2010). The influence of alcohol on behavioral recovery after mTBI in mice. J. Neurotrauma 27, 555-563.

27. Baratz, R., Tweedie, D., Rubovitch, V., Luo, W., Yoon, J.S., Hoffer, B.J., Greig, N.H., and Pick, C.G. (2011). Tumor necrosis factor-alpha synthesis inhibitor, 3,6'-dithiothalidomide, reverses behavioral impairments induced by minimal traumatic brain injury in mice. J. Neurochem. 118, 1032-1042.

28. Baratz, R., Tweedie, D., Wang, J.Y., Rubovitch, V., Luo, W.M., Hoffer, B.J., Greig, N.H., and Pick, C.G. (2015). Transiently lowering tumor necrosis factor-alpha synthesis ameliorates neuronal cell loss and cognitive impairments induced by minimal traumatic brain injury in mice. J. Neuroinflammation 12, 45.

29. Barzo, P., Marmarou, A., Fatouros, P., Corwin, F., and Dunbar, J (1996). Magnetic resonance imaging-monitored acute blood-brain barrier changes in experimental traumatic brain injury. J. Neurosurg. 85, 1113-1121.

30. Barzo, P., Marmarou, A., Fatouros, P., Hayasaki, K., and Corwin, F. (1997). Contribution of vasogenic and cellular edema to traumatic brain swelling measured by diffusion-weighted imaging. J. Neurosurg. 87, 900-907.

31. BeitYannai, E., Zhang, R.L., Trembovler, V., Samuni, A., and Shohami, E. (1996). Cerebroprotective effect of stable nitroxide radicals in closed head injury in the rat. Brain Res. 717, 22-28.

32. BeitYannai, E., Kohen, R., Horowitz, M., Trembovler, V., and Shohami, E. (1997). Changes of biological reducing activity in rat brain following closed head injury: a cyclic voltammetry study in normal and heat-acclimated rats. J. Cereb. Blood Flow Metab. 17, 273-279.

33. Beni, S.M., Kohen, R., Reiter, R.J., Tan, D.X., and Shohami, E. (2004). Melatonin-induced neuroprotection after closed head injury is associated with increased brain antioxidants and attenuated latephase activation of NF-kappa B and AP-1. FASEB J. 18, 149-151.

34. Benromano, T., Defrin, R., Ahn, A.H., Zhao, J., Pick, C.G., and Levy, D. (2015). Mild closed head injury promotes a selective trigeminal hypernociception: implications for the acute emergence of post-traumatic headache. Eur. J. Pain 19, 621-628.

35. Biber, N., Toklu, H.Z., Solakoglu, S., Gultomruk, M., Hakan, T., Berkman, Z., and Dulger, F.G. (2009). Cysteinyl-leukotriene receptor antagonist montelukast decreases blood-brain barrier permeability but does not prevent oedema formation in traumatic brain injury. Brain Inj. 23, 577-584.

36. Blanie, A., Vigue, B., Benhamou, D., Duranteau, J., and Geeraerts, T. (2012). The frontal lobe and thalamus have different sensitivities to hypoxia-hypotension after traumatic brain injury: a microdialysis study in rats. J. Neurotrauma 29, 2782-2790.

37. Bodjarian, N., Jamali, S., Boisset, N., and Tadie, M. (1997). Strong expression of GFAP mRNA in rat hippocampus after a closed-head injury. Neuroreport 8, 3951-3956.
38. Boeck, C.R., Carbonera, L.S., Milioli, M.E., Constantino, L.C., Garcez, M.L., Rezin, G.T., Scaini, G., and Streck, E.L. (2013). Mitochondrial respiratory chain and creatine kinase activities following trauma brain injury in brain of mice preconditioned with $\mathrm{N}$-methylD-aspartate. Mol. Cell. Biochem. 384, 129-137.

39. Borges, N., Cerejo, A., Santos, A., Sarmento, A., and Azevedo, I. (2004). Changes in rat cerebral mitochondrial succinate dehydrogenase activity after brain trauma. Int. J. Neurosci. 114, 217-227.

40. Bouzat, P., Millet, A., Boue, Y., Pernet-Gallay, K., Trouve-Buisson, T., Gaide-Chevronnay, L., Barbier, E.L., and Payen, J.F. (2013). Changes in brain tissue oxygenation after treatment of diffuse traumatic brain injury by erythropoietin. Crit. Care Med. 41, 1316-1324.

41. Bree, D., and Levy, D. (2018). Development of CGRP-dependent pain and headache related behaviours in a rat model of concussion: implications for mechanisms of post-traumatic headache. Cephalalgia 38, 246-258.

42. Buchele, F., Morawska, M.M., Schreglmann, S.R., Penner, M., Muser, M., Baumann, C.R., and Noain, D. (2016). Novel rat model of weight drop-induced closed diffuse traumatic brain injury compatible with electrophysiological recordings of vigilance states. J. Neurotrauma 33, 1171-1180.

43. Buki, A., Koizumi, H., and Povlishock, J.T. (1999). Moderate posttraumatic hypothermia decreases early calpain-mediated proteolysis and concomitant cytoskeletal compromise in traumatic axonal injury. Exp. Neurol. 159, 319-328.

44. Bye, N., Habgood, M.D., Callaway, J.K., Malakooti, N., Potter, A., Kossmann, T., and Morganti-Kossmann, M.C. (2007). Transient neuroprotection by minocycline following traumatic brain injury is associated with attenuated microglial activation but no changes in cell apoptosis or neutrophil infiltration. Exp. Neurol. 204, 220-233.

45. Caner, H., Can, A., Atalay, B., Erdogan, B., Albayrak, A.H., Kilinc, K., Bavbek, M., and Altinors, N. (2004). Early effects of mild brain trauma on the cytoskeletal proteins neurofilament(160) and MAP(2), and the preventive effects of mexilitine. Acta Neurochirurg. 146, 611-621.

46. Caron, A.M., and Stephenson, R. (2015). Sleep deprivation does not affect neuronal susceptibility to mild traumatic brain injury in the rat. Nat. Sci. Sleep 7, 63-72.

47. Carron, S.F., Yan, E.B., Alwis, D.S., and Rajan, R. (2016). Differential susceptibility of cortical and subcortical inhibitory neurons and astrocytes in the long term following diffuse traumatic brain injury. J. Comp. Neurol. 524, 3530-3560.

48. Chen, Y., Lomnitski, L., Michaelson, D.M., and Shohami, E. (1997). Motor and cognitive deficits in apolipoprotein E-deficient mice after closed head injury. Neuroscience 80, 1255-1262.

49. Chen, M.F., Huang, T.Y., Kuo, Y.M., Yu, L., Chen, H.I., and Jen, C.Y.J. (2013). Early postinjury exercise reverses memory deficits and retards the progression of closed-head injury in mice. J. Physiol. 591, 985-1000.

50. Chorny, I., Bsorai, R., Artru, A.A., Talmor, D., Benkoviz, V., Roytblat, L., and Shapira, Y. (1999). Albumin or hetastarch improves neurological outcome and decreases volume of brain tissue necrosis but not brain edema following closed-head trauma in rats. J. Neurosurg. Anesthesiol. 11, 273-281.

51. Cohen-Yeshurun, A., Trembovler, V., Alexandrovich, A., Ryberg, E., Greasley, P.J., Mechoulam, R., Shohami, E., and Leker, R.R. (2011). N-arachidonoyl-L-serine is neuroprotective after traumatic brain injury by reducing apoptosis. J. Cereb. Blood Flow Metab. 31, 1768-1777.

52. Çolak, T., Duman, C., Bamac, B., Aydin, A., Özbek, A., Yildiz, K., and Bicer, U. (2010). Ischemia modified albumin levels following mild closed head trauma in the rat. Turkiye Klinikleri Tip Bilimleri Dergisi 30, 1171-1176.

53. Collins-Praino, L.E., Arulsamy, A., Katharesan, V., and Corrigan, F. (2018). The effect of an acute systemic inflammatory insult on the chronic effects of a single mild traumatic brain injury. Behav. Brain Res. 336, 22-31.

54. Corrigan, F., Vink, R., Blumbergs, P.C., Masters, C.L., Cappai, R., and van den Heuvel, C. (2012). Characterisation of the effect of knockout of the amyloid precursor protein on outcome following mild traumatic brain injury. Brain Res. 1451, 87-99.

55. Costa, T., Constantino, L.C., Mendonca, B.P., Pereira, J.G., Herculano, B., Tasca, C.I., and Boeck, C.R. (2010). N-Methyl-D-aspartate preconditioning improves short-term motor deficits outcome after mild traumatic brain injury in mice. J. Neurosci. Res. 88, 1329-1337. 
56. Crack, P., Gould, J., Bye, N., Ross, S., Ali, U., Habgood, M., Morganti-Kossman, C., Saunders, N., and Hertzog, P.; Victorian Neurotrauma Research Group. (2009). The genomic profile of the cerebral cortex after closed head injury in mice: effects of minocycline. J. Neural Transm. 116, 1-12.

57. Creeley, C.E., Wozniak, D.F., Bayly, P.V., Olney, J.W., and Lewis, L.M. (2004). Multiple episodes of mild traumatic brain injury result in impaired cognitive performance in mice. Acad. Emerg. Med. 11, 809-819.

58. Cui, C.M., Gao, J.L., Cui, Y., Sun, L.Q., Wang, Y.C., Wang, K.J., Li, R., Tian, Y.X., and Cui, J.Z. (2015). Chloroquine exerts neuroprotection following traumatic brain injury via suppression of inflammation and neuronal autophagic death. Mol. Med. Rep. 12, 2323-2328.

59. Czigner, A., Mihaly, A., Farkas, O., Buki, A., Krisztin-Peva, B., Dobo, E., and Barzo, P. (2004). Dynamics and regional distribution of c-fos protein expression in rat brain after a closed head injury. Int. J. Mol. Med. 14, 247-252.

60. Czigner, A., Mihaly, A., Farkas, O., Buki, A., Krisztin-Peva, B., Dobo, E., and Barzo, P. (2007). Kinetics of the cellular immune response following closed head injury. Acta Neurochirurg. 149, 281289.

61. De Oliveira, P.A., Ben, J., Matheus, F.C., Schwarzbold, M.L., Moreira, E.L.G., Rial, D., Walz, R., and Prediger, R.D. (2017) Moderate traumatic brain injury increases the vulnerability to neurotoxicity induced by systemic administration of 6-hydroxydopamine in mice. Brain Res. 1663, 78-86.

62. Dehghan, F., Hadad, M.K., Asadikram, G., Najafipour, H., and Shahrokhi, N. (2013). Effect of melatonin on intracranial pressure and brain edema following traumatic brain injury: role of oxidative stresses. Arch. Med. Res. 44, 251-258.

63. Ding, J.Y., Kreipke, C.W., Schafer, P., Schafer, S., Speirs, S.L., and Rafols, J.A. (2009). Synapse loss regulated by matrix metalloproteinases in traumatic brain injury is associated with hypoxia inducible factor-1 alpha expression. Brain Res. 1268, 125-134.

64. Ding, J.Y., Kreipke, C.W., Speirs, S.L., Schafer, P., Schafer, S., and Rafols, J.A. (2009). Hypoxia-inducible factor-1 alpha signaling in aquaporin upregulation after traumatic brain injury. Neurosci. Lett. $453,68-72$

65. Ding, K., Wang, H.D., Xu, J.G., Li, T., Zhang, L., Ding, Y., Zhu, L., He, J., and Zhou, M.L. (2014). Melatonin stimulates antioxidan enzymes and reduces oxidative stress in experimental traumatic brain injury: the Nrf2-ARE signaling pathway as a potential mechanism. Free Radic. Biol. Med. 73, 1-11.

66. Ding, K., Wang, H.D., Wu, Y., Zhang, L., Xu, J.G., Li, T., Ding, Y., Zhu, L., and He, J. (2015). Rapamycin protects against apoptotic neuronal death and improves neurologic function after traumatic brain injury in mice via modulation of the mTOR-p53-Bax axis. J. Surg. Res. 194, 239-247.

67. Diskin, T., Tal-Or, P., Erlich, S., Mizrachy, L., Alexandrovich, A., Shohami, E., and Pinkas-Kramarski, R. (2005). Closed head injury induces upregulation of Beclin 1 at the cortical site of injury. J. Neurotrauma 22, 750-762.

68. Dore-Duffy, P., Owen, C., Balabanov, R., Murphy, S., Beaumont, T., and Rafols, J.A. (2000). Pericyte migration from the vascular wall in response to traumatic brain injury. Microvasc. Res. 60, 55-69.

69. Doulames, V.M., Vilcans, M., Lee, S., and Shea, T.B. (2015). Social interaction attenuates the extent of secondary neuronal damage following closed head injury in mice. Front. Behav. Neurosci. 9, 275

70. Edut, S., Rubovitch, V., Schreiber, S., and Pick, C.G. (2011). The intriguing effects of ecstasy (MDMA) on cognitive function in mice subjected to a minimal traumatic brain injury (mTBI). Psychopharmacology 214, 877-889.

71. Edut, S., Rubovitch, V., Rehavi, M., Schreiber, S., and Pick, C.G. (2014). A study on the mechanism by which MDMA protects against dopaminergic dysfunction after minimal traumatic brain injury (mTBI) in mice. J. Mol. Neurosci. 54, 684-697.

72. Eilig, I., Rachinsky, M., Artru, A.A., Alonchin, A., Kapuler, V., Tarnapolski, A., and Shapira, Y. (2001). The effect of treatment with albumin, hetastarch, or hypertonic saline on neurological status and brain edema in a rat model of closed head trauma combined with uncontrolled hemorrhage and concurrent resuscitation in rats. Anesth. Analg. 92, 669-675.

73. Elangovan, V., Kohen, R., and Shohami, E. (2000). Neurological recovery from closed head injury is impaired in diabetic rats. J. Neurotrauma 17, 1013-1027.
74. Engelborghs, K., Verlooy, J., Van Deuren, B., Van Reempts, J., and Borgers, M. (1997). Intracranial pressure in a modified experimental model of closed head injury. Acta Neurochir. Suppl. 70, $123-125$.

75. Engelborghs, K., Haseldonckx, M., Van Reempts, J., Van Rossem, K., Wouters, L., Borgers, M., and Verlooy, J. (2000). Impaired autoregulation of cerebral blood flow in an experimental model of traumatic brain injury. J. Neurotrauma 17, 667-677.

76. Erlich, S., Shohami, E., and Pinkas-Kramarski, R. (2000). Closed head injury induces up-regulation of ErbB-4 receptor at the site of injury. Mol. Cell. Neurosci. 16, 597-608.

77. Erlich, S., Alexandrovich, A., Shohami, E., and Pinkas-Kramarski, R. (2007). Rapamycin is a neuroprotective treatment for traumatic brain injury. Neurobiol. Dis. 26, 86-93.

78. Esen, F., Erdem, T., Aktan, D., Kalayci, R., Cakar, N., Kaya, M., and Telci, L. (2003). Effects of magnesium administration on brain edema and blood-brain barrier breakdown after experimental traumatic brain injury in rats. J. Neurosurg. Anesthesiol. 15, 119125 .

79. Esquivel, A.O., Sherman, S.S., Bir, C.A., and Lemos, S.E. (2017). The interaction of intramuscular ketorolac (toradol) and concussion in a rat model. Ann. Biomed. Eng. 45, 1581-1588.

80. Evanson, N.K., Guilhaume-Correa, F., Herman, J.P., and Goodman, M.D. (2018). Optic tract injury after closed head traumatic brain injury in mice: a model of indirect traumatic optic neuropathy. PLos One 13, e0197346.

81. Ezaki, J., Shimada, R., Shibuya, M., and Kibayashi, K. (2016). Hippocampal neuronal degeneration in the traumatic brain injury mouse: non-trivial effect of scalp incision. Neurol. Res. 38, 994 1002 .

82. Ezra, Y., Oron, L., Moskovich, L., Roses, A.D., Beni, S.M., Shohami, E., and Michaelson, D.M. (2003). Apolipoprotein E4 decreases whereas apolipoprotein E3 increases the level of secreted amyloid precursor protein after closed head injury. Neuroscience 121, 315325 .

83. Feldman, Z., Gurevitch, B., Artru, A.A., Oppenheim, A., Shohami, E., Reichenthal, E., and Shapira, Y. (1996). Effect of magnesium given 1 hour after head trauma on brain edema and neurological outcome. J. Neurosurg. 85, 131-137.

84. Feldman, Z., Gurevitch, B., Artru, A.A., Shapira, Y., and Reichenthal, E. (1997). Neurologic outcome with hemorrhagic hypotension after closed head trauma in rats: effect of early versus delayed conservative fluid therapy. J. Trauma 43, 667-672.

85. Flierl, M.A., Stahel, P.F., Beauchamp, K.M., Morgan, S.J., Smith, W.R., and Shohami, E. (2009). Mouse closed head injury model induced by a weight-drop device. Nat. Protoc. 4, 1328-1337.

86. Foda, M.A.A., and Marmarou, A. (1994). A new model of diffuse brain injury in rats 2: morphological characterization. J. Neurosurg. 80, 301-313.

87. Forstner, P., Rehman, R., Anastasiadou, S., Haffner-Luntzer, M., Sinske, D., Ignatius, A., Roselli, F., and Knoell, B. (2018). Neuroinflammation after traumatic brain injury (TBI) is enhanced in activating transcription factor 3 (ATF3) mutant mice. J. Neurotrauma 35, 2317-2329

88. Fox, L.C., Davies, D.R., Scholl, J.L., Watt, M.J., and Forster, G.L. (2016). Differential effects of glucocorticoid and mineralocorticoid antagonism on anxiety behavior in mild traumatic brain injury. Behav. Brain Res. 312, 362-365.

89. Fujiki, M., Kubo, T., Kamida, T., Sugita, K., Hikawa, T., Abe, T., Ishii, K., and Kobayashi, H. (2008). Neuroprotective and antiamnesic effect of donepezil, a nicotinic acetylcholine-receptor activator, on rats with concussive mild traumatic brain injury. J. Clin. Neurosci. $15,791-796$.

90. Gao, M., Dong, Q., Yao, H., Lu, Y.Z., Ji, X.C., Zou, M.M., Yang, Z.J., Xu, M.H., and Xu, R.X. (2017). Systemic administration of induced neural stem cells regulates complement activation in mouse closed head injury models. Sci. Rep. 7, 45989.

91. Gao, M., Dong, Q., Lu, Y.Z., Yao, H., Zou, M.M., Yang, Y., Zhu, J.W., Yang, Z.J., Xu, M.H., and Xu, R.X. (2018). Induced neural stem cell-derived astrocytes modulate complement activation and mediate neuroprotection following closed head injury. Cell Death Dis. 9, 101.

92. Genis, L., Chen, Y., Shohami, E., and Michaelson, D.M. (2000). Tau hyperphosphorylation in apolipoprotein E-deficient and control mice after closed head injury. J. Neurosci. Res. 60, 559-564. 
93. Girgis, H., Palmier, B., Croci, N., Soustrat, M., Plotkine, M., and Marchand-Leroux, C. (2013). Effects of selective and non-selective cyclooxygenase inhibition against neurological deficit and brain oedema following closed head injury in mice. Brain Res. 1491, 78-87.

94. Goodman, M.D., Makley, A.T., Huber, N.L., Clarke, C.N., Friend, L.A.W., Schuster, R.M., Bailey, S.R., Barnes, S.L., Dorlac, W.C., Johannigman, J.A., Lentsch, A.B., and Pritts, T.A. (2011). Hypobaric hypoxia exacerbates the neuroinflammatory response to traumatic brain injury. J. Surg. Res. 165, 30-37.

95. Griesemer, D., and Mautes, A.M. (2007). Closed head injury causes hyperexcitability in rat hippocampal CA1 but not in CA3 pyramidal cells. J. Neurotrauma 24, 1823-1832.

96. Grigoriants, O.O., Pravdenkova, S.V., Andersen, B.J., and Desiderio, D.M. (1995). Alteration of opioid peptide concentrations in the rat pituitary following survivable closed head injury. Neurochem. Res. 20, 827-831.

97. Gu, Y., Zhao, Y., Qian, K., and Sun, M. (2015). Taurine attenuates hippocampal and corpus callosum damage, and enchances neurological recovery after closed head injury in rats. Neuroscience 291, 331-340.

98. Guida, F., Boccella, S., Iannotta, M., De Gregorio, D., Giordano, C., Belardo, C., Romano, R., Palazzo, E., Scafuro, M.A., Serra, N., de Novellis, V., Rossi, F., Maione, S., and Luongo, L. (2017). Palmitoylethanolamide reduces neuropsychiatric behaviors by restoring cortical electrophysiological activity in a mouse model of mild traumatic brain injury. Front. Pharmacol. 8, 95.

99. Gupta, R.K., and Prasad, S. (2016). Age-dependent alterations in the interactions of NF-kappa B and N-myc with GLT-1/EAAT2 promoter in the pericontusional cortex of mice subjected to traumatic brain injury. Mol. Neurobiol. 53, 3377-3388.

100. Gurevich, B., Talmor, D., Artru, A.A., Katcko, L., Geva, D., Gurman, G., and Shapira, Y. (1997). Brain edema, hemorrhagic necrosis volume, and neurological status with rapid infusion of $0.45 \%$ saline or $5 \%$ dextrose in $0.9 \%$ saline after closed head trauma in rats. Anesth. Analg. 84, 554-559.

101. Gurevich, B., Artru, A.A., Lam, A.M., Mueller, A.L., Merkind, V., Talmor, D., Katchko, L., and Shapira, Y. (1998). Neuroprotective effects of NPS 846, a novel N-methyl-D-aspartate receptor antagonist, after closed head trauma in rats. J. Neurosurg. 88, 1066-1074.

102. Hakan, T., Toklu, H.Z., Biber, N., Ozevren, H., Solakoglu, S., Demirturk, P., and Aker, F.V. (2010). Effect of COX-2 inhibitor meloxicam against traumatic brain injury-induced biochemical, histopathological changes and blood-brain barrier permeability. Neurol. Res. 32, 629-635.

103. Hayasaki, K., Marmarou, A., Barzo, P., Fatouros, P., and Corwin, F. (1997). Detection of brain atrophy following traumatic brain injury using gravimetric techniques. Acta Neurochir. Suppl. 70, 75-77.

104. Heffernan, M.E., Huang, W., Sicard, K.M., Bratane, B.T., Sikoglu, E.M., Zhang, N.Y., Fisher, M., and King, J.A. (2013). Multi-modal approach for investigating brain and behavior changes in an animal model of traumatic brain injury. J. Neurotrauma 30, 1007-1012.

105. Hehar, H., Yeates, K., Kolb, B., Esser, M.J. and Mychasiuk, R. (2015). Impulsivity and concussion in juvenile rats: examining molecular and structural aspects of the frontostriatal pathway. PLos One 10, e0139842.

106. Hehar, H., Yu, K., Ma, I., and Mychasiuk, R. (2016). Paternal age and diet: the contribution of a father's experience to susceptibility for post-concussion symptomology. Neuroscience 332, 61-75.

107. Heim, L.R., Bader, M., Edut, S., Rachmany, L., Baratz-Goldstein, R., Lin, R., Elpaz, A., Qubty, D., Bikovski, L., Rubovitch, V., Schreiber, S., and Pick, C.G. (2017). The invisibility of mild traumatic brain injury: impaired cognitive performance as a silent symptom. J. Neurotrauma 34, 2518-2528.

108. Hellal, F., Pruneau, D., Palmier, B., Faye, P., Croci, N., Plotkine, M., and Marchand-Verrecchia, C. (2003). Detrimental role of bradykinin B-2 receptor in a murine model of diffuse brain injury. J. Neurotrauma 20, 841-851.

109. Hellal, F., Bonnefont-Rousselot, D., Croci, N., Palmier, B., Plotkine, M., and Marchand-Verrecchia, C. (2004). Pattern of cerebral edema and hemorrhage in a mice model of diffuse brain injury. Neurosci. Lett. 357, 21-24

110. Henninger, N., Dutzmann, S., Sicard, K.M., Kollmar, R., Bardutzky, J., and Schwab, S. (2005). Impaired spatial learning in a novel rat model of mild cerebral concussion injury. Exp. Neurol. 195, 447457.
111. Henninger, N., Sicard, K.M., Li, Z.X., Kulkarni, P., Dutzmann, S., Urbanek, C., Schwab, S., and Fisher, M. (2007). Differential recovery of behavioral status and brain function assessed with functional magnetic resonance imaging after mild traumatic brain injury in the rat. Crit. Care Med. 35, 2607-2614.

112. Henninger, N., Bouley, J., Sikoglu, E.M., An, J., Moore, C.M., King, J.A., Bowser, R., Freeman, M.R., and Brown, R.H., Jr. (2016). Attenuated traumatic axonal injury and improved functional outcome after traumatic brain injury in mice lacking Sarm1. Brain 139, 1094 1105.

113. Hicdonmez, T., Kanter, M., Tiryaki, M., Parsak, T., and Cobanoglu, S. (2006). Neuroprotective effects of $\mathrm{N}$-acetylcysteine on experimental closed head trauma in rats. Neurochem. Res. 31, 473-481.

114. Higashida, T., Kreipke, C.W., Rafols, J.A., Peng, C.Y., Schafer, S., Schafer, P., Ding, J.Y., Dornbos, D., Li, X.H., Guthikonda, M., Rossi, N.F., and Ding, Y.C. (2011). The role of hypoxia-inducible factor-la, aquaporin-4, and matrix metalloproteinase-9 in blood-brain barrier disruption and brain edema after traumatic brain injury. J. Neurosurg. 114, 92-101.

115. Hsiang, J.N., Wang, J.Y., Ip, S.M., Ng, H.K., Stadlin, A., Yu, A.L., and Poon, W.S. (1997). The time course and regional variations of lipid peroxidation after diffuse brain injury in rats. Acta Neurochir. (Wien) $139,464-468$.

116. Hsieh, T.H., Kang, J.W., Lai, J.H., Huang, Y.Z., Rotenberg, A., Chen, K.Y., Wang, J.Y., Chan, S.Y., Chen, S.C., Chiang, Y.H., and Peng, C.W. (2017). Relationship of mechanical impact magnitude to neurologic dysfunction severity in a rat traumatic brain injury model. PLos One 12, e0178186.

117. Huang, W., Chen, Y., Shohami, E., and Weinstock, M. (1999). Neuroprotective effect of rasagiline, a selective monoamine oxidase$\mathrm{B}$ inhibitor, against closed head injury in the mouse. Eur. J. Pharmacol. 366, 127-135.

118. Hutchison, J.S., Derrane, R.E., Johnston, D.L., Gendron, N., Barnes, D., Fliss, H., King, W.J., Rasquinha, I., MacManus, J., Robertson, G.S., and MacKenzie, A.E. (2001). Neuronal apoptosis inhibitory protein expression after traumatic brain injury in the mouse. J. Neurotrauma 18, 1333-1347.

119. Iino, M., Nakatome, M., Ogura, Y., Fujimura, H., Kuroki, H., Inoue, H., Ino, Y., Fujii, T., Terao, T., and Matoba, R. (2003). Real-time PCR quantitation of FE65 a beta-amyloid precursor protein-binding protein after traumatic brain injury in rats. Int. J. Legal Med. 117, $153-159$

120. Imer, M., Omay, B., Uzunkol, A., Erdem, T., Sabanci, P.A., Karasu, A., Albayrak, S.B., Sencer, A., Hepgul, K., and Kaya, M. (2009). Effect of magnesium, MK-801 and combination of magnesium and MK-801 on blood-brain barrier permeability and brain edema after experimental traumatic diffuse brain injury. Neurol. Res. 31, 977981.

121. Israel, I., Ohsiek, A., Al-Momani, E., Albert-Weissenberger, C., Stetter, C., Mencl, S., Buck, A.K., Kleinschnitz, C., Samnick, S., and Siren, A.L. (2016). Combined [(18)F]DPA-714 micro-positron emission tomography and autoradiography imaging of microglia activation after closed head injury in mice. J. Neuroinflammation 13 , 140 .

122. Israelsson, C., Wang, Y., Kylberg, A., Pick, C.G., Hoffer, B.J., and Ebendal, T. (2009). Closed head injury in a mouse model results in molecular changes indicating inflammatory responses. J. Neurotrauma 26, 1307-1314.

123. Itsekson-Hayosh, Z., Shavit-Stein, E., Katzav, A., Rubovitch, V., Maggio, N., Chapman, J., Harnof, S., and Pick, C.G. (2016). Minimal traumatic brain injury in mice: protease-activated receptor 1 and thrombin-related changes. J. Neurotrauma 33, 1848-1854.

124. Ivashkova, Y., Svetnitsky, A., Mayzler, O., Pruneau, D., Benifla, M., Fuxman, Y., Cohen, A., Artru, A.A., and Shapira, Y. (2006). Bradykinin B2 receptor antagonism with LF 18-1505T reduces brain edema and improves neurological outcome after closed head trauma in rats. J. Trauma 61, 879-885.

125. Jin, W., Ni, H.B., Dai, Y.X., Wang, H.D., Lu, T.Y., Wu, J., Jiang, J.A., and Liang, W.B. (2010). Effects of tert-butylhydroquinone on intestinal inflammatory response and apoptosis following traumatic brain injury in mice. Mediators Inflamm. 2010, 502564.

126. Jin, W., Kong, J., Lu, T., Wang, H., Ni, H., Wu, J., Dai, Y., Jiang, J., and Liang, W. (2011). Erythropoietin prevents secondary brain injury induced by cortical lesion in mice: possible involvement of Nrf2 signaling pathway. Ann. Clin. Lab. Sci. 41, 25-32. 
127. Jin, W., Kong, J., Wang, H.D., Wu, J., Lu, T.Y., Jiang, J., Ni, H.B., and Liang, W.B. (2011). Protective effect of tert-butylhydroquinone on cerebral inflammatory response following traumatic brain injury in mice. Injury 42, 714-718.

128. Jin, W., Wu, J., Wang, H.D., Kong, J., Ni, H.B., and Liang, W.B. (2011). Erythropoietin administration modulates pulmonary Nrf2 signaling pathway after traumatic brain injury in mice. J. Trauma 71, 680-686.

129. Jindal, A., Mahesh, R., Bhatt, S., and Pandey, D. (2017). Molecular modifications by regulating cAMP signaling and oxidant-antioxidan defence mechanisms, produce antidepressant-like effect: a possible mechanism of etazolate aftermaths of impact accelerated traumatic brain injury in rat model. Neurochem. Int. 111, 3-11.

130. Johnstone, V.P.A., Yan, E.B., Alwis, D.S., and Rajan, R. (2013) Cortical hypoexcitation defines neuronal responses in the immediate aftermath of traumatic brain injury. PLos One 8, e63454.

131. Kahveci, F.S., Kahveci, N., Alkan, T., Goren, B., Korfali, E., and Ozluk, K. (2001). Propofol versus isoflurane anesthesia under hypothermic conditions: effects on intracranial pressure and local cerebral blood flow after diffuse traumatic brain injury in the rat. Surg. Neurol. 56, 206-214.

132. Kallakuri, S., Kreipke, C.W., Rossi, N., Rafols, J.A., and Petrov, T. (2007). Spatial alterations in endothelin receptor expression are temporally associated with the altered microcirculation after brain trauma. Neurol. Res. 29, 362-368.

133. Kallakuri, S., Bandaru, S., Zakaria, N., Shen, Y.M., Kou, Z.F., Zhang, L.Y., Haacke, E.M., and Cavanaugh, J.M. (2015). Traumatic brain injury by a closed head injury device induces cerebral blood flow changes and microhemorrhages. J. Clin. Imaging Sci. 5, 52.

134. Kamm, K., VanderKolk, W., Lawrence, C., Jonker, M., and Davis, A.T. (2006). The effect of traumatic brain injury upon the concentration and expression of interieukin- 1 beta and interleukin-10 in the rat. J. Trauma 60, 152-157.

135. Kaplanski, J., Pruneau, D., Asa, I., Artru, A.A., Azez, A., Ivashkova Y., Rudich, Z., and Shapira, Y. (2002). LF 16-0687 Ms, a bradykinin B2 receptor antagonist, reduces brain edema and improves long-term neurological function recovery after closed head trauma in rats. J. Neurotrauma 19, 953-964.

136. Kaplanski, J., Asa, I., Artru, A.A., Azez, A., Ivashkova, Y., Rudich, Z., Pruneau, D., and Shapira, Y. (2003). LF 16-0687 Ms, a new bradykinin $\mathrm{B} 2$ receptor antagonist, decreases ex vivo brain tissue prostaglandin E2 synthesis after closed head trauma in rats. Resuscitation 56, 207-213.

137. Katoh, H., Sima, K., Nawashiro, H., Wada, K., and Chigasaki, H. (1997). The effect of MK-801 on extracellular neuroactive amino acids in hippocampus after closed head injury followed by hypoxia in rats. Brain Res. 758, 153-162.

138. Katoh, H., Shima, K., Nawashiro, H., Wada, K., and Chigasaki, H (1998). Selective hippocampal damage to hypoxia after mild closed head injury in the rat. Acta Neurochir. Suppl. 71, 247-249.

139. Kayipmaz, A.E., Erdem, R., Yilmaz, C., Deniz, E.E., Kavalci, C., Ozdemir, A., Guler, I., Caferoglu, E., Kalyoncu, F.S., and Guven, O. (2017). The effect of pycnogenol (R) on spatial learning and memory in rats with experimental closed head injury. Haseki Tip Bulteni 55, 101-105.

140. Khalin, I., Alyautdin, R., Wong, T.W., Gnanou, J., Kocherga, G., and Kreuter, J. (2016). Brain-derived neurotrophic factor delivered to the brain using poly (lactide-co-glycolide) nanoparticles improves neurological and cognitive outcome in mice with traumatic brain injury. Drug Deliv. 23, 3520-3528.

141. Khandelwal, V.K.M., Singh, P., Ravingerova, T., Gregory, M., Gandhi, H., and Chaudhary, M. (2017). Comparison of differen osmotic therapies in a mouse model of traumatic brain injury. Pharmacol. Rep. 69, 176-184.

142. Khuman, J., Meehan, W.P., Zhu, X.X., Qiu, J.H., Hoffmann, U., Zhang, J., Giovannone, E., Lo, E.H., and Whalen, M.J. (2011). Tumor necrosis factor alpha and Fas receptor contribute to cognitive deficits independent of cell death after concussive traumatic brain injury in mice. J. Cereb. Blood Flow Metab. 31, 778-789.

143. Kim, H.J., and Han, S.J. (2017). A simple rat model of mild traumatic brain injury: a device to reproduce anatomical and neurological changes of mild traumatic brain injury. Peerj 5, e2818.

144. Kita, H., and Marmarou, A. (1994). The cause of acute brain swelling after the closed head injury in rats. Acta Neurochir. Suppl. (Wien) $60,452-455$.
145. Koc, R.K., Kurtsoy, A., Pasaoglu, H., Karakucuk, E.I., Oktem, I.S., and Meral, M. (1999). Lipid peroxidation and oedema in experimental brain injury: comparison of treatment with methylprednisolone, tirilazad mesylate and vitamin E. Res. Exp. Med. (Berl.) 199, 21-28

146. Kofman, I., and Abookasis, D. (2015). Dual-wavelength laser speckle imaging for monitoring brain metabolic and hemodynamic response to closed head traumatic brain injury in mice. J. Biomed. Opt. 20, 106009

147. Koizumi, H., and Povlishock, J.T. (1998). Posttraumatic hypothermia in the treatment of axonal damage in an animal model of traumatic axonal injury. J. Neurosurg. 89, 303-309.

148. Koyfman, L., Kaplanski, J., Artru, A.A., Talmor, D., Rubin, M., and Shapira, Y. (2000). Inhibition of cyclooxygenase 2 by nimesulide decreases prostaglandin E2 formation but does not alter brain edema or clinical recovery after closed head injury in rats. J. Neurosurg. Anesthesiol. 12, 44-50.

149. Lado, W.E., and Persinger, M.A. (2003). Mechanical impacts to the skulls of rats produce specific deficits in maze performance and weight loss: evidence for apoptosis of cortical neurons and implications for clinical neuropsychology. Percept. Mot. Skills 97, 11151127.

150. Lammie, G.A., Piper, I.R., Thomson, D., and Brannan, F. (1999). Neuropathologic characterization of a rodent model of closed head injury-addition of clinically relevant secondary insults does not significantly potentiate brain damage. J. Neurotrauma 16, 603-615.

151. Leibowitz, A., Brotfain, E., Koyfman, L., Klein, M., Hess, S. Zlotnik, A., and Boyko, M. (2018). Treatment of combined traumatic brain injury and hemorrhagic shock with fractionated blood products versus fresh whole blood in a rat model. Eur. J. Trauma Emerg. Surg. Jan 17. doi: 10.1007/s00068-018-0908-9. [Epub ahead of print]

152. Leinhase, I., Holers, V.M., Thurman, J.M., Harhausen, D., Schmidt, O.I., Pietzcker, M., Taha, M.E., Rittirsch, D., Huber-Lang, M., Smith, W.R., Ward, P.A., and Stahel, P.F. (2006). Reduced neuronal cell death after experimental brain injury in mice lacking a functional alternative pathway of complement activation. BMC Neurosci. 7, 55

153. Leinhase, I., Schmidt, O.I., Thurman, J.M., Hossini, A.M., Rozanski, M., Taha, M.E., Scheffler, A., John, T., Smith, W.R., Holers, V.M., and Stahel, P.F. (2006). Pharmacological complement inhibition at the $\mathrm{C} 3$ convertase level promotes neuronal survival, neuroprotective intracerebral gene expression, and neurological outcome after traumatic brain injury. Exp. Neurol. 199, 454-464.

154. Leinhase, I., Rozanski, M., Harhausen, D., Thurman, J.M., Schmidt, O.I., Hossini, A.M., Taha, M.E., Rittirsch, D., Ward, P.A., Holers, V.M., Ertel, W., and Stahel, P.F. (2007). Inhibition of the alternative complement activation pathway in traumatic brain injury by a monoclonal anti-factor B antibody: a randomized placebo-controlled study in mice. J. Neuroinflammation 4, 13

155. Lesniak, A., Pick, C.G., Misicka, A., Lipkowski, A.W., and Sacharczuk, M. (2016). Biphalin protects against cognitive deficits in a mouse model of mild traumatic brain injury (mTBI). Neuropharmacology 101, 506-518.

156. Lesniak, A., Leszczynski, P., Bujalska-Zadrozny, M., Pick, C.G., and Sacharczuk, M. (2017). Naloxone exacerbates memory impairments and depressive-like behavior after mild traumatic brain injury (mTBI) in mice with upregulated opioid system activity. Behav. Brain Res. 326, 209-216.

157. Lestage, P., Iris-Hugot, A., Gandon, M.H., and Lepagnol, J. (1998) Involvement of nicotinergic mechanisms in thyrotropin-releasing hormone-induced neurologic recovery after concussive head injury in the mouse. Eur. J. Pharmacol. 357, 163-169.

158. Li, Y.H., Zhang, C.L., Zhang, X.Y., Zhou, H.X., and Meng, L.L. (2015). Effects of mild induced hypothermia on hippocampal connexin 43 and glutamate transporter 1 expression following traumatic brain injury in rats. Mol. Med. Rep. 11, 1991-1996.

159. Li, S., Li, H., He, X.F., Li, G., Zhang, Q., Liang, F.Y., Jia, H.H., Li, J.C., Huang, R., Pei, Z., Wang, L.J., and Zhang, Y. (2016). Transgenic over-expression of slit2 enhances disruption of blood-brain barrier and increases cell death after traumatic brain injury in mice. Neurosci. Lett. 631, 85-90.

160. Ling, H.P., Li, W., Zhou, M.L., Tang, Y., Chen, Z.R., and Hang, C.H. (2013). Expression of intestinal myeloid differentiation primary response protein 88 (Myd88) following experimental traumatic brain injury in a mouse model. J. Surg. Res. 179, E227-E234. 
161. Liu, P., Li, Y.S., Quartermain, D., Boutajangout, A., and Ji, Y. (2013). Inhaled nitric oxide improves short term memory and reduces the inflammatory reaction in a mouse model of mild traumatic brain injury. Brain Res. 1522, 67-75.

162. Liu, Z.W., Wang, H.D., Shi, X.F., Li, L.W., Zhou, M.L., Ding, H., Yang, Y.Q., Li, X., and Ding, K. (2017). DL-3-n-butylphthalide (NBP) provides neuroprotection in the mice models after traumatic brain injury via Nrf2-ARE signaling pathway. Neurochem. Res. 42, 1375-1386.

163. Lomnitski, L., Kohen, R., Chen, Y., Shohami, E., Trembovler, V., Vogel, T., and Michaelson, D.M. (1997). Reduced levels of antioxidants in brains of apolipoprotein E-deficient mice following closed head injury. Pharmacol. Biochem. Behav. 56, 669-673.

164. Lomnitski, L., Chapman, S., Hochman, A., Kohen, R., Shohami, E., Chen, Y., Trembovler, V., and Michaelson, D.M. (1999). Antioxidant mechanisms in apolipoprotein $\mathrm{E}$ deficient mice prior to and following closed head injury. Biochim. Biophys. Acta Mol. Basis Dis. 1453, 359-368.

165. Lomnitski, L., Nyska, A., Shohami, E., Chen, Y., and Michaelson, D.M. (2000). Increased levels of intracellular iron in the brains of ApoE-deficient mice with closed head injury. Exp. Toxicol. Pathol. 52, 177-183.

166. Lopez-Rodriguez, A.B., Acaz-Fonseca, E., Giatti, S., Caruso, D., Viveros, M.P., Melcangi, R.C., and Garcia-Segura, L.M. (2015). Correlation of brain levels of progesterone and dehydroepiandrosterone with neurological recovery after traumatic brain injury in female mice. Psychoneuroendocrinology 56, 1-11.

167. Lopez-Rodriguez, A.B., Acaz-Fonseca, E., Viveros, M.P., and Garcia-Segura, L.M. (2015). Changes in cannabinoid receptors, aquaporin 4 and vimentin expression after traumatic brain injury in adolescent male mice. Association with edema and neurological deficit. PLoS One 10, e0128782.

168. Lopez-Rodriguez, A.B., Siopi, E., Finn, D.P., Marchand-Leroux, C., Garcia-Segura, L.M., Jafarian-Tehrani, M., and Viveros, M.P. (2015). CB1 and CB2 cannabinoid receptor antagonists prevent minocycline-induced neuroprotection following traumatic brain injury in mice. Cereb. Cortex 25, 35-45.

169. Lopez-Rodriguez, A.B., Acaz-Fonseca, E., Spezzano, R., Giatti, S., Caruso, D., Viveros, M.P., Melcangi, R.C., and Garcia-Segura, L.M. (2016). Profiling neuroactive steroid levels after traumatic brain injury in male mice. Endocrinology 157, 3983-3993

170. Lopez-Rodriguez, A.B., Mela, V., Acaz-Fonseca, E., Garcia-Segura, L.M., and Viveros, M.P. (2016). CB2 cannabinoid receptor is involved in the anti-inflammatory effects of leptin in a model of traumatic brain injury. Exp. Neurol. 279, 274-282.

171. Lorber, A., Artru, A.A., Lam, M.A., Mueller, L.A., Karpas, Z., Roytblat, L., and Shapira, Y. (2000). NPS 1506: a novel NMDA receptor antagonist: neuroprotective effects in a model of closed head trauma in rats. J. Neurosurg. Anesthesiol. 12, 345-355.

172. Lu, J., Moochhala, S., Kaur, C., and Ling, E.A. (2000). Changes in apoptosis-related protein (p53, Bax, Bcl-2 and Fos) expression with DNA fragmentation in the central nervous system in rats after closed head injury. Neurosci. Lett. 290, 89-92.

173. Lu, J., Moochhala, S., Kaur, C., and Ling, E.A. (2001). Cellular inflammatory response associated with breakdown of the blood-brain barrier after closed head injury in rats. J. Neurotrauma 18, 399-408.

174. Lu, X.Y., Wang, H.D., Xu, J.G., Ding, K., and Li, T. (2014). Pretreatment with tert-butylhydroquinone attenuates cerebral oxidative stress in mice after traumatic brain injury. J. Surg. Res. 188, 206-212.

175. Maghool, F., Khaksari, M., and Khachki, A.S. (2013). Differences in brain edema and intracranial pressure following traumatic brain injury across the estrous cycle: involvement of female sex steroid hormones. Brain Res. 1497, 61-72.

176. Manaka, S., and Sano, K. (1978). Thyrotropin-releasing-hormone tartrate (TRH-T) shortens concussion effects following head impact in mice. Neurosci. Lett. 8, 255-258.

177. Mann, A., Smoum, R., Trembovler, V., Alexandrovich, A., Breuer, A., Mechoulam, R., and Shohami, E. (2015). Palmitoyl serine: an endogenous neuroprotective endocannabinoid-like entity after traumatic brain injury. J. Neuroimmune Pharmacol. 10, 356-363.

178. Marciano, D., Shohami, E., Kloog, Y., Alexandrovitch, A., Brandeis, R., and Goelman, G. (2007). Neuroprotective effects of the Ras inhibitor S-trans-trans-farnesylthiosalicylic acid, measured by diffusion-weighted imaging after traumatic brain injury in rats. J. Neurotrauma 24, 1378-1386.
179. Marmarou, A., Foda, M.A.A., Vandenbrink, W., Campbell, J., Kita, H., and Demetriadou, K. (1994). A new model of diffuse brain injury in rats 1: pathophysiology and biomechanics. J. Neurosurg. 80, 291300 .

180. Marschner, L., Ahmed, T., Schreurs, A., Lechat, B., Van Leuven, F., Mogensen, J., and Balschun, D. (2016). Mild traumatic brain injury of Tau.P301L mice results in an impairment of neural plasticity. Arch. Neurosci. 3, e38039.

181. Marschner, L., Schreurs, A., Lechat, B., Mogensen, J., Roebroek, A., Ahmed, T., and Balschun, D. (2018). Single mild traumatic brain injury results in transiently impaired spatial long-term memory and altered search strategies. Behav. Brain Res. Feb 27. pii: S01664328(18)30289-4. doi: 10.1016/j.bbr.2018.02.040. [Epub ahead of print]

182. Mautes, A.E.M., Thome, D., Steudel, W.I., Nacimiento, A.C., Yang, Y., and Shohami, E. (2001). Changes in regional energy metabolism after closed head injury in the rat. J. Mol. Neurosci. 16, 33-39.

183. Mayzler, O., Leon, A., Eilig, I., Fuxman, Y., Benifla, M., Freixo, P.C., Gurevich, B., Agassi, R., Artru, A.A., and Shapria, Y. (2006). The effect of hypertonic (3\%) saline with and without furosemide on plasma osmolality, sodium concentration, and brain water content after closed head trauma in rats. J. Neurosurg. Anesthesiol. 18, 24-31.

184. Mencl, S., Hennig, N., Hopp, S., Schuhmann, M.K., AlbertWeissenberger, C., Siren, A.L., and Kleinschnitz, C. (2014). FTY720 does not protect from traumatic brain injury in mice despite reducing posttraumatic inflammation. J. Neuroimmunol. 274, 125-131.

185. Meyer, D.L., Davies, D.R., Barr, J.L., Manzerra, P., and Forster, G.L. (2012). Mild traumatic brain injury in the rat alters neuronal number in the limbic system and increases conditioned fear and anxiety-like behaviors. Exp. Neurol. 235, 574-587.

186. Michelson, A.M., Jadot, G., and Puget, K. (1988). Treatment of brain trauma with liposomal superoxide dismutase. Free Radic. Res. Commun. 4, 209-224.

187. Milman, A., Rosenberg, A., Weizman, R., and Pick, C.G. (2005). Mild traumatic brain injury induces persistent cognitive deficits and behavioral disturbances in mice. J. Neurotrauma 22, 1003-1010.

188. Milman, A., Zohar, O., Maayan, R., Weizman, R., and Pick, C.G. (2008). DHEAS repeated treatment improves cognitive and behavioral deficits after mild traumatic brain injury. Eur. Neuropsychopharmacol. 18, 181-187.

189. Moojen, V.K.M., Damiani-Neves, M., Bavaresco, D.V., Pescador, B.B., Comim, C.M., Quevedo, J., and Boeck, C.R. (2012). NMDA preconditioning prevents object recognition memory impairment and increases brain viability in mice exposed to traumatic brain injury. Brain Res. 1466, 82-90.

190. Moor, E., Kohen, R., Reiter, R.J., and Shohami, E. (2001). Closed head injury increases extracellular levels of antioxidants in rat hippocampus in vivo: an adaptive mechanism? Neurosci. Lett. 316 , 169-172.

191. Moor, E., Shohami, E., Kanevsky, E., Grigoriadis, N., Symeonidou, C., and Kohen, R. (2006). Impairment of the ability of the injured aged brain in elevating urate and ascorbate. Exp. Gerontol. 41, 303-311.

192. Mustafa, G., Hou, J.M., Tsuda, S., Nelson, R., Sinharoy, A., Wilkie, Z., Pandey, R., Caudle, R.M., Neubert, J.K., Thompson, F.J., and Bose, P. (2016). Trigeminal neuroplasticity underlies allodynia in a preclinical model of mild closed head traumatic brain injury (cTBI). Neuropharmacology 107, 27-39.

193. Mustafa, G., Hou, L.M., Nelson, R., Tsuda, S., Jahan, M., Mohammad, N.S., Watts, J.V., Thompson, F.J., and Bose, P. (2017). Mild closed head traumatic brain injury-induced changes in monoamine neurotransmitters in the trigeminal subnuclei of a rat model: mechanisms underlying orofacial allodynias and headache. Neural Regen. Res. 12, 981-986.

194. Mychasiuk, R., Farran, A., Angoa-Perez, M., Briggs, D., Kuhn, D., and Esser, M.J. (2014). A novel model of mild traumatic brain injury for juvenile rats. J. Vis. Exp. (94), doi: 10.3791/51820.

195. Mychasiuk, R., Hehar, H., Farran, A., and Esser, M.J. (2014). Mean girls: sex differences in the effects of mild traumatic brain injury on the social dynamics of juvenile rat play behaviour. Behav Brain Res. 259, 284-291.

196. Mychasiuk, R., Hehar, H., Ma, I., and Esser, M.J. (2015). Dietary intake alters behavioral recovery and gene expression profiles in the brain of juvenile rats that have experienced a concussion. Front. Behav. Neurosci. 9, 17. 
197. Mychasiuk, R., Hehar, H., Ma, I., Kolb, B., and Esser, M.J. (2015). The development of lasting impairments: a mild pediatric brain injury alters gene expression, dendritic morphology, and synaptic connectivity in the prefrontal cortex of rats. Neuroscience 288,145 155 .

198. Mychasiuk, R., Hehar, H., van Waes, L., and Esser, M.J. (2015) Diet, age, and prior injury status differentially alter behavioral outcomes following concussion in rats. Neurobiol. Dis. 73, 1-11.

199. Mychasiuk, R., Hehar, H., Candy, S., Ma, I., and Esser, M.J. (2016) The direction of the acceleration and rotational forces associated with mild traumatic brain injury in rodents effect behavioural and molecular outcomes. J. Neurosci. Methods 257, 168-178.

200. Nadler, V., Biegon, A., Beit-Yannai, E., Adamchik, J., and Shohami, E. (1995). 45Ca accumulation in rat brain after closed head injury; attenuation by the novel neuroprotective agent HU-211. Brain Res. $685,1-11$.

201. Nadler, Y., Alexandrovich, A., Grigorladis, N., Hartmann, T., Rao, K.S.J., Shohami, E., and Stein, R. (2008). Increased expression of the gamma-secretase components presenilin-1 and nicastrin in activated astrocytes and microglia following traumatic brain injury. Glia 56, $552-567$.

202. Namjoshi, D.R., Cheng, W.H., Bashir, A., Wilkinson, A., Stukas, S. Martens, K.M., Whyte, T., Abebe, Z.A., McInnes, K.A., Cripton, P.A., and Wellington, C.L. (2017). Defining the biomechanical and biological threshold of murine mild traumatic brain injury using CHIMERA (Closed Head Impact Model of Engineered Rotational Acceleration). Exp. Neurol. 292, 80-91.

203. Nawashiro, H., Shima, K., and Chigasaki, H. (1995). Immediate cerebrovascular responses to closed-head injury in the rat J. Neurotrauma 12, 189-197.

204. Nichols, J.N., Hagan, K.L., and Floyd, C.L. (2017). Evaluation of touchscreen chambers to assess cognition in adult mice: effect of training and mild traumatic brain injury. J. Neurotrauma 34, $2481-$ 2494.

205. Nilsson, B., and Nordstrom, C.H. (1977). Rate of cerebral energy consumption in concussive head injury in the rat. J. Neurosurg. 47 , 274-281.

206. Okuyama, S., Imagawa, Y., Ogawa, S., Araki, H., Otomo, S., Sakagawa, T., Yamada, S., and Shima, K. (1993). Effect of VA-045 on a closed head injury model in rats. Life Sci. 53, P1273-P278.

207. Okuyama, S., Kawashima, N., Araki, H., Otomo, S., and Shima, K. (1994). Effects of an apovincaminic acid-derivative VA-045 on neuronal-activity in rat-brain stem reticular-formation. Life Sci. 55, 1577-1584.

208. Okuyama, S., Yamada, S., Ogawa, S., Kawashima, N., Tomisawa, K., Shima, K., and Kamata, K. (1996). Effect of VA-045 on central noradrenergic neuronal system in rats. Gen. Pharmacol. 27, 1013-1017.

209. Okuyama, S., Yamada, S., Ogawa, S., Shima, K., Kamata, K., and Tomisawa, K. (1997). Effect of VA-045, a novel apovincaminic acid derivative, on closed head injury-induced neurological dysfunction in aged rats. Neurol. Res. 19, 300-304.

210. Ommaya, A.K., Geller, A., and Parsons, L.C. (1971). The effect of experimental head injury on one-trial learning in rats. Int. J. Neurosci. 1, 371-378.

211. Otto, V.I., Stahel, P.F., Rancan, M., Kariya, K., Shohami, E., Yatsiv, I., Eugster, H.P., Kossmann, T., Trentz, O., and Morganti-Kossmann, M.C. (2001). Regulation of chemokines and chemokine receptors after experimental closed head injury. Neuroreport 12, 2059-2064.

212. Ozay, R., Turkoglu, E., Gurer, B., Dolgun, H., Evirgen, O., Erguder, B.I., Hayirli, N., Gurses, L., Sekerci, Z., and Yilmaz, E.R. (2017) Does decorin protect neuronal tissue via its antioxidant and antiinflammatory activity from traumatic brain injury? An experimental study. World. Neurosurg. 97, 407-415.

213. Ozay, R., Turkoglu, M.E., Gurer, B., Dolgun, H., Evirgen, O., Erguder, B.I., Hayirli, N., Gurses, L., and Sekerci, Z. (2017). The protective effect of omeprazole against traumatic brain injury: an experimental study. World Neurosurg. 104, 634-643.

214. Ozturk, E., Demirbilek, S., Kadir But, A., Saricicek, V., Gulec, M., Akyol, O., and Ozcan Ersoy, M. (2005). Antioxidant properties of propofol and erythropoietin after closed head injury in rats. Prog. Neuropsychopharmacol. Biol. Psychiatry 29, 922-927.

215. Panikashvili, D., Mechoulam, R., Beni, S.M., Alexandrovich, A., and Shohami, E. (2005). CB1 cannabinoid receptors are involved in neuroprotection via NF-kappa B inhibition. J. Cereb Blood Flow Metab. 25, 477-484.
216. Pascual, J.M., Solivera, J., Prieto, R., Barrios, L., Lopez-Larrubia, P., Cerdan, S., and Roda, J.M. (2007). Time course of early metabolic changes following diffuse traumatic brain injury in rats as detected by H-1 NMR spectroscopy. J. Neurotrauma 24, 944-959.

217. Petronilho, F., Feier, G., de Souza, B., Gughelmi, C., Constantino, L.S., Walz, R., Quevedo, J., and Dal-Pizzol, F. (2010). Oxidative stress in brain according to traumatic brain injury intensity. J. Surg. Res. 164, 316-320.

218. Petrov, T., and Rafols, J.A. (2001). Acute alterations of endothelin-1 and iNOS expression and control of the brain microcirculation after head trauma. Neurol. Res. 23, 139-143.

219. Petrov, T., Underwood, B.D., Braun, B., Alousi, S.S., and Rafols, J.A. (2001). Upregulation of iNOS expression and phosphorylation of eIF-2 alpha are paralleled by suppression of protein synthesis in rat hypothalamus in a closed head trauma model. J. Neurotrauma 18 , 799-812.

220. Pruneau, D., Chorny, I., Benkovitz, V., Artru, A., Roitblat, L., and Shapira, Y. (1999). Effect of LF 16-0687MS, a new nonpeptide bradykinin B-2 receptor antagonist, in a rat model of closed head trauma. J. Neurotrauma 16, 1057-1065.

221. Qian, K., Gu, Y., Zhao, Y.M., Li, Z.Z. and Sun, M. (2014). Citicoline protects brain against closed head injury in rats through suppressing oxidative stress and calpain over-activation. Neurochem. Res. 39, 1206-1218.

222. Qin, Y., Li, G.L., Xu, X.H., Sun, Z.Y., Gu, J.W., and Gao, F.B. (2018). Brain structure alterations and cognitive impairment following repetitive mild head impact: an in vivo MRI and behavioral study in rat. Behav. Brain Res. 340, 41-48.

223. Rachinsky, M., Pruneau, D., Artru, A.A., Kapuler, V., Alonchin, A., Smolanezki, Y., and Shapira, Y. (2001). The importance of kinin antagonist treatment timing in closed head trauma. J. Trauma 51, 944-948.

224. Rachmany, L., Tweedie, D., Rubovitch, V., Yu, Q.S., Li, Y.Z., Wang, J.Y., Pick, C.G., and Greig, N.H. (2013). Cognitive impairments accompanying rodent mild traumatic brain injury involve p53-dependent neuronal cell death and are ameliorated by the tetrahydrobenzothiazole PFT-alpha. PLoS One 8, e79837.

225. Rancan, M., Otto, V.I., Hans, V.H.J., Gerlach, I., Jork, R., Trentz, O., Kossmann, T., and Morganti-Kossmann, M.C. (2001). Upregulation of ICAM-1 and MCP-1 but not of MIP-2 and sensorimotor deficit in response to traumatic axonal injury in rats. J. Neurosci. Res. 63, 438446.

226. Rasouli, J., Lekhraj, R., White, N.M., Flamm, E.S., Pilla, A.A. Strauch, B., and Casper, D. (2012). Attenuation of interleukin-1beta by pulsed electromagnetic fields after traumatic brain injury. Neurosci. Lett. 519, 4-8.

227. Ren, H.X., Yang, Z., Luo, C.M., Zeng, H.T., Li, P., Kang, J.X., Wan, J.B., He, C.W., and Su, H.X. (2017). Enriched endogenous omega-3 fatty acids in mice ameliorate parenchymal cell death after traumatic brain injury. Mol. Neurobiol. 54, 3317-3326.

228. Rodriguez-Grande, B., Obenaus, A., Ichkova, A., Aussudre, J., Bessy, T., Barse, E., Hiba, B., Catheline, G., Barriere, G., and Badaut, J. (2018). Gliovascular changes precede white matter damage and long-term disorders in juvenile mild closed head injury. Glia. Apr 17. doi: 10.1002/glia.23336. [Epub ahead of print]

229. Rooker, S., Jorens, P.G., Van Reempts, J., Borgers, M., and Verlooy, J. (2003). Continuous measurement of intracranial pressure in awake rats after experimental closed head injury. J. Neurosci. Methods 131, 75-81.

230. Rooker, S., Jander, S., Van Reempts, J., Stoll, G., Jorens, P.G., Borgers, M., and Verlooy, J. (2006). Spatiotemporal pattern of neuroinflammation after impact-acceleration closed head injury in the rat. Mediators Inflamm. 2006, 90123

231. Rosahl, S.K., Schuhmann, M.U., Thomas, S., Brinker, T., and Samii, M. (1998). Brain-stem auditory evoked potential monitoring in experimental diffuse brain injury. Acta Neurochir. Suppl. 71, 88-90.

232. Rossi, J.L., Todd, T., Bazan, N.G., and Belayev, L. (2013). Inhibition of myosin light-chain kinase attenuates cerebral edema after traumatic brain injury in postnatal mice. J. Neurotrauma 30, 1672-1679.

233. Rubovitch, V., Shachar, A., Werner, H., and Pick, C.G. (2011) Does IGF-1 administration after a mild traumatic brain injury in mice activate the adaptive arm of ER stress? Neurochem. Int. 58, 443-446.

234. Ruozi, B., Belletti, D., Forni, F., Sharma, A., Muresanu, D., Mossler, H., Vandelli, M.A., Tosi, G., and Sharma, H.S. (2014). Poly (D, 
L-lactide-co-glycolide) nanoparticles loaded with cerebrolysin display neuroprotective activity in a rat model of concussive head injury. CNS Neurol. Disord. Drug Targets 13, 1475-1482.

235. Sabir, M., Gaudreault, P.O., Freyburger, M., Massart, R., BlanchetCohen, A., Jaber, M., Gosselin, N., and Mongrain, V. (2015). Impact of traumatic brain injury on sleep structure, electrocorticographic activity and transcriptome in mice. Brain Behav. Immun. 47, 118130.

236. Salberg, S., Yamakawa, G., Christensen, J., Kolb, B., and Mychasiuk, R. (2017). Assessment of a nutritional supplement containing resveratrol, prebiotic fiber, and omega-3 fatty acids for the prevention and treatment of mild traumatic brain injury in rats. Neuroscience $365,146-157$.

237. Semple, B.D., Bye, N., Ziebell, J.M., and Morganti-Kossmann, M.C. (2010). Deficiency of the chemokine receptor CXCR2 attenuates neutrophil infiltration and cortical damage following closed head injury. Neurobiol. Dis. 40, 394-403.

238. Sen, S., Goldman, H., Morehead, M., Murphy, S., and Phillis, J.W. (1993). Oxypurinol inhibits free-radical release from the cerebralcortex of closed-head injured rats. Neurosci. Lett. 162, 117-120.

239. Shapira, Y., Artru, A.A., and Lam, A.M. (1992). Ketamine decreases cerebral infarct volume and improves neurological outcome following experimental head trauma in rats. J. Neurosurg. Anesthesiol. 4, 231-240.

240. Shapira, Y., Setton, D., Artru, A.A., and Shohami, E. (1993). Bloodbrain barrier permeability, cerebral edema, and neurologic function after closed head injury in rats. Anesth. Analg. 77, 141-148.

241. Shapira, Y., Talmor, D., Artru, A.A., Rubin, M., Holkuvski, A., Merkind, V., and Kaplanski, J. (1998). Effects of closed head trauma and lipopolysaccharide on body temperature, brain tissue water content, and PGE2 production in rats. J. Neurosurg. Anesthesiol. 10, 94-100.

242. Shapira, M., Licht, A., Milman, A., Pick, C.G., Shohami, E., and Eldar-Finkelman, H. (2007). Role of glycogen synthase kinase-3 beta in early depressive behavior induced by mild traumatic brain injury. Mol. Cell. Neurosci. 34, 571-577.

243. Sharma, A.C., Misra, M., Prat, R., Alden, K., Sam, A.D., Markiv, V.Z., Dujovny, M., and Ferguson, J.L. (1998). A differential response of diffuse brain injury on the concentrations of endothelin and nitric oxide in the plasma and brain regions in rats. Neurol. Res. 20, 632-636.

244. Sharma, H.S., Patnaik, R., Patnaik, S., Mohanty, S., Sharma, A., and Vannemreddy, P. (2007). Antibodies to serotonin attenuate closed head injury induced blood brain barrier disruption and brain pathology. Ann. N. Y. Acad. Sci. 1122, 295-312.

245. Sharma, H.S., Patnaik, R., Patnaik, S., Sharma, A., Mohanty, S., and Vannemreddy, P. (2010). Antibodies to dynorphin a (1-17) attenuate closed head injury induced blood-brain barrier disruption, brain edema formation and brain pathology in the rat. Acta Neurochir. Suppl. 106, 301-306.

246. Sharma, A., Chandran, R., Barry, E.S., Bhomia, M., Hutchison, M.A., Balakathiresan, N.S., Grunberg, N.E., and Maheshwari, R.K. (2014). Identification of serum microRNA signatures for diagnosis of mild traumatic brain injury in a closed head injury model. PLoS One 9, e112019.

247. Shaw, N.A. (1985). A simple device for experimentally concussing the rat. Physiol. Behav. 35, 637-639.

248. Shein, N.A., Horowitz, M., Alexandrovich, A.G., Tsenter, J., and Shohami, E. (2005). Heat acclimation increases hypoxia-inducible factor 1 alpha and erythropoietin receptor expression: implication for neuroprotection after closed head injury in mice. J. Cereb. Blood Flow Metab. 25, 1456-1465.

249. Shein, N.A., Grigoriadis, N., Alexandrovich, A.G., Simeonidou, C., Spandou, E., Tsenter, J., Yatsiv, I., Horowitz, M., and Shohami, E. (2008). Differential neuroprotective properties of endogenous and exogenous erythropoietin in a mouse model of traumatic brain injury. J. Neurotrauma 25, 112-123.

250. Shenaq, M., Kassem, H., Peng, C., Schafer, S., Ding, J.Y., Fredrickson, V., Guthikonda, M., Kreipke, C.W., Rafols, J.A., and Ding, Y. (2012). Neuronal damage and functional deficits are ameliorated by inhibition of aquaporin and HIF1alpha after traumatic brain injury (TBI). J. Neurol. Sci. 323, 134-140.

251. Sherman, M., Liu, M.M., Birnbaum, S., Wolf, S.E., Minei, J.P., and Gatson, J.W. (2016). Adult obese mice suffer from chronic secondary brain injury after mild TBI. J. Neuroinflammation 13, 171 .
252. Shochat, A., and Abookasis, D. (2015). Differential effects of early postinjury treatment with neuroprotective drugs in a mouse model using diffuse reflectance spectroscopy. Neurophotonics 2, 015001.

253. Shohami, E., Shapira, Y., and Cotev, S. (1988). Experimental closed head injury in rats: prostaglandin production in a noninjured zone. Neurosurgery 22, 859-863.

254. Shohami, E., Shapira, Y., Yadid, G., Reisfeld, N., and Yedgar, S. (1989). Brain phospholipase A2 is activated after experimental closed head injury in the rat. J. Neurochem. 53, 1541-1546.

255. Shohami, E., Shapira, Y., Rosenthal, J., and Reches, A. (1991). Superoxide dismutase activity is not affected by closed head injury in rats. J. Basic Clin. Physiol. Pharmacol. 2, 103-109.

256. Shohami, E., Glantz, L., Nates, J., and Feuerstein, G. (1992). The mixed lipoxygenase/cyclooxygenase inhibitor SK\&F 105809 reduces cerebral edema after closed head injury in rat. J. Basic Clin. Physiol. Pharmacol. 3, 99-107.

257. Shohami, E., Novikov, M., and Mechoulam, R. (1993). A nonpsychotropic cannabinoid, HU-211, has cerebroprotective effects after closed head injury in the rat. J. Neurotrauma 10, 109-119.

258. Shohami, E., Novikov, M., Bass, R. Yamin, A. and Gallily, R. (1994). Closed head injury triggers early production of TNF alpha and IL- 6 by brain tissue. J. Cereb. Blood Flow Metab. 14, 615-619.

259. Shohami, E., Novikov, M., and Horowitz, M. (1994). Long term exposure to heat reduces edema formation after closed head injury in the rat. Acta Neurochir. Suppl. (Wien) 60, 443-445.

260. Shohami, E., Novikov, M., and Bass, R. (1995). Long-term effect of HU-211, a novel non-competitive NMDA antagonist, on motor and memory functions after closed head injury in the rat. Brain Res. 674 , $55-62$.

261. Shohami, E., Bass, R., Wallach, D., Yamin, A., and Gallily, R. (1996). Inhibition of tumor necrosis factor alpha (TNF alpha) activity in rat brain is associated with cerebroprotection after closed head injury. J. Cereb. Blood Flow Metab. 16, 378-384.

262. Shohami, E., Gallily, R., Mechoulam, R., Bass, R., and BenHur, T. (1997). Cytokine production in the brain following closed head injury: dexanabinol (HU-211) is a novel TNF-alpha inhibitor and an effective neuroprotectant. J. Neuroimmunol 72, 169-177.

263. Sifringer, M., Stefovska, V., Endesfelder, S., Stahel, P.F., Genz, K., Dzietko, M., Ikonomidou, C., and Felderhoff-Mueser, U. (2007). Activation of caspase-1 dependent interleukins in developmental brain trauma. Neurobiol. Dis. 25, 614-622.

264. Signoretti, S., Di Pietro, V., Vagnozzi, R., Lazzarino, G., Amorini, A.M., Belli, A., D'Urso, S., and Tavazzi, B. (2010). Transient alterations of creatine, creatine phosphate, $\mathrm{N}$-acetylaspartate and highenergy phosphates after mild traumatic brain injury in the rat. Mol. Cell. Biochem. 333, 269-277.

265. Sikoglu, E.M., Heffernan, M.E., Tam, K., Sicard, K.M., Bratane, B.T., Quan, M., Fisher, M., and King, J.A. (2014). Enhancement in cognitive function recovery by granulocyte-colony stimulating factor in a rodent model of traumatic brain injury. Behav. Brain Res. 259, 354-356.

266. Singh, K., Trivedi, R., Devi, M.M., Tripathi, R.P., and Khushu, S. (2016). Longitudinal changes in the DTI measures, anti-GFAP expression and levels of serum inflammatory cytokines following mild traumatic brain injury. Exp. Neurol. 275, 427-435.

267. Singh, K., Trivedi, R., Haridas, S., Manda, K., and Khushu, S. (2016). Study of neurometabolic and behavioral alterations in rodent model of mild traumatic brain injury: a pilot study. NMR Biomed. $29,1748-1758$.

268. Siopi, E., Cho, A.H., Homsi, S., Croci, N., Plotkine, M., MarchandLeroux, C., and Jafarian-Tehrani, M. (2011). Minocycline restores sAPP alpha levels and reduces the late histopathological consequences of traumatic brain injury in mice. J. Neurotrauma 28, 2135 2143.

269. Siopi, E., Calabria, S., Plotkine, M., Marchand-Leroux, C., and Jafarian-Tehrani, M. (2012). Minocycline restores olfactory bulb volume and olfactory behavior after traumatic brain injury in mice. J. Neurotrauma 29, 354-361.

270. Siopi, E., Llufriu-Daben, G., Fanucchi, F., Plotkine, M., MarchandLeroux, C., and Jafarian-Tehrani, M. (2012). Evaluation of late cognitive impairment and anxiety states following traumatic brain injury in mice: the effect of minocycline. Neurosci. Lett. 511, 110 115.

271. Siopi, E., Llufriu-Daben, G., Cho, A.H., Vidal-Lletjos, S., Plotkine, M., Marchand-Leroux, C., and Jafarian-Tehranr, M. (2013). Etazolate, 
an alpha-secretase activator, reduces neuroinflammation and offers persistent neuroprotection following traumatic brain injury in mice. Neuropharmacology 67, 183-192.

272. Smith, D.W., Bailes, J.E., Fisher, J.A., Robles, J., Turner, R.C., and Mills, J.D. (2012). Internal jugular vein compression mitigates traumatic axonal injury in a rat model by reducing the intracranial slosh effect. Neurosurgery 70, 740-746.

273. Song, Q., Xie, D.J., Pan, S.Y., and Xu, W.J. (2015). Rapamycin protects neurons from brain contusion-induced inflammatory reaction via modulation of microglial activation. Mol. Med. Rep. 12, 72037210.

274. Stahel, P.F., Kossmann, T., MorgantiKossmann, M.C., Hans, V.H.J., and Barnum, S.R. (1997). Experimental diffuse axonal injury induces enhanced neuronal C5a receptor mRNA expression in rats. Mol. Brain Res. 50, 205-212.

275. Stahel, P.F., Kariya, K., Shohami, E., Barnum, S.R., Eugster, H.P., Trentz, O., Kossmann, T., and Morganti-Kossmann, M.C. (2000). Intracerebral complement $\mathrm{C} 5$ a receptor (CD88) expression is regulated by TNF and lymphotoxin-alpha following closed head injury in mice. J. Neuroimmunol. 109, 164-172.

276. Stahel, P.F., Shohami, E., Younis, F.M., Kariya, K., Otto, V.I., Lenzlinger, P.M., Grosjean, M.B., Eugster, H.P., Trentz, O., Kossmann, T., and Morganti-Kossmann, M.C. (2000). Experimenta closed head injury: analysis of neurological outcome, blood-brain barrier dysfunction, intracranial neutrophil infiltration, and neuronal cell death in mice deficient in genes for pro-inflammatory cytokines. J. Cereb. Blood Flow Metab. 20, 369-380.

277. Stahel, P.F., Flierl, M.A., Morgan, B.P., Persigehl, I., Stoll, C., Conrad, C., Touban, B.M., Smith, W.R., Beauchamp, K., Schmidt, O.I., Ertel, W., and Leinhase, I. (2009). Absence of the complement regulatory molecule CD59a leads to exacerbated neuropathology after traumatic brain injury in mice. J. Neuroinflammation 6, 2.

278. Stemper, B.D., Shah, A.S., Chiariello, R., Olsen, C.M., Budde, M.D. Glavaski-Joksimovic, A., McCrea, M., Kurpad, S.N., and Pintar, F.A (2016). Prediction of post-concussive behavioral changes in a rodent model based on head rotational acceleration characteristics. Ann. Biomed. Eng. 44, 3252-3265.

279. Stone, J.R., Walker, S.A., and Povlishock, J.T. (1999). The visualization of a new class of traumatically injured axons through the use of a modified method of microwave antigen retrieval. Acta Neuropathol. 97, 335-345.

280. Sun, M., Zhao, Y.M., Gu, Y., and Zhang, Y.Z. (2015). Protective effects of taurine against closed head injury in rats. J. Neurotrauma $32,66-74$.

281. Suzuki, M., Nishina, M., Endo, M., Matsushita, K., Tetsuka, M., Shima, K., and Okuyama, S. (1997). Decrease in cerebral free magnesium concentration following closed head injury and effects of VA-045 in rats. Gen. Pharmacol. 28, 119-121.

282. Talmor, D., Roytblat, L., Artru, A.A., Yuri, O., Koyfman, L., Katchko, L., and Shapira, Y. (1998). Phenylephrine-induced hypertension does not improve outcome after closed head trauma in rats. Anesth. Analg. 87, 574-578.

283. Talmor, D., Shapira, Y., Artru, A.A., Gurevich, B., Merkind, V., Katchko, L., and Reichenthal, E. (1998). 0.45\% saline and 5\% dextrose in water, but not $0.9 \%$ saline or $5 \%$ dextrose in $0.9 \%$ saline worsen brain edema two hours after closed head trauma in rats. Anesth. Analg. 86, 1225-1229.

284. Tamas, A., Zsombok, A., Farkas, O., Reglodi, D., Pal, J., Buki, A., Lengvari, I., Povlishock, J.T., and Doczi, T. (2006). Postinjury administration of pituitary adenylate cyclase activating polypeptide (PACAP) attenuates traumatically induced axonal injury in rats. J. Neurotrauma 23, 686-695.

285. Tang, Y.P., Noda, Y., Hasegawa, T., and Nabeshima, T. (1997). A concussive-like brain injury model in mice (I): impairment in learning and memory. J. Neurotrauma 14, 851-862.

286. Tang, Y.P., Noda, Y., Hasegawa, T., and Nabeshima, T. (1997). A concussive-like brain injury model in mice (II): selective neuronal loss in the cortex and hippocampus. J. Neurotrauma 14, 863-873.

287. Tang, Y.P., Noda, Y., Hasegawa, T., and Nabeshima, T. (1997). (+)Eburnamenine-14-carboxylic acid (2-nitroxyethyl) ester (VA-045), putative cognitive enhancer, facilitates recovery from concussive brain injury-induced learning and memory impairments in mice. Behav. Brain Res. 83, 195-199.

288. Tang, Y.P., Noda, Y., Hasegawa, T., and Nabeshima, T. (1997). Effects of VA-045 on learning and memory deficits in traumatic brain injury (TBI)-induced retrograde and anterograde amnesic mice. Br. J. Pharmacol. 122, 257-264.

289. Tang, Y.P., Noda, Y., and Nabeshima, T. (1997). A synergistic interaction between dopamine D1 and D2 receptor subtypes in the memory impairments induced by concussive brain injury (CBI) in mice. Behav. Brain Res. 83, 189-193.

290. Tashlykov, V., Katz, Y., Volkov, A., Gazit, V., Schreiber, S., Zohar, O., and Pick, C.G. (2009). Minimal traumatic brain injury induce apoptotic cell death in mice. J. Mol. Neurosci. 37, 16-24.

291. Tehranian, R., Andell-Jonsson, S., Beni, S.M., Yatsiv, I., Shohami, E., Bartfai, T., Lundkvist, J., and Iverfeldt, K. (2002). Improved recovery and delayed cytokine induction after closed head injury in mice with central overexpression of the secreted isoform of the interleukin-1 receptor antagonist. J. Neurotrauma 19, 939-951.

292. Thau-Zuchman, O., Shohami, E., Alexandrovich, A.G., and Leker, R.R. (2012). Subacute treatment with vascular endothelial growth factor after traumatic brain injury increases angiogenesis and gliogenesis. Neuroscience 202, 334-341.

293. Thau-Zuchman, O., Shohami, E., Alexandrovich, A.G., Trembovler, V., and Leker, R.R. (2012). The anti-inflammatory drug carprofen improves long-term outcome and induces gliogenesis after traumatic brain injury. J. Neurotrauma 29, 375-384.

294. Thomas, S., Tabibnia, F., Schuhmann, M.U., Brinker, T., and Samii, M. (2000). Influences of secondary injury following traumatic brain injury in developing versus adult rats. Acta Neurochir. Suppl. 76, 397-399.

295. Toklu, H.Z., Hakan, T., Biber, N., Solakolu, S., Ogunc, A.V., and Sener, G. (2009). The protective effect of alpha lipoic acid against traumatic brain injury in rats. Free Radic. Res. Commun. 43, 658667.

296. Topçu, I., Gümüşer, G., Bayram, E., Aras, F., Cetin, I., Temiz, C., and Civi, M. (2013). The effects of lornoxicam on brain edema and blood brain barrier following diffuse traumatic brain injury in rats. Ulus. Travma Acil Cerrahi Derg. 19, 294-298.

297. Trembovler, V., Beit-Yannai, E., Younis, F., Gallily, R., Horowitz, M., and Shohami, E. (1999). Antioxidants attenuate acute toxicity of tumor necrosis factor-alpha induced by brain injury in rat. J. Interferon Cytokine Res. 19, 791-795.

298. Tu, T.W., Williams, R.A., Lescher, J.D., Jikaria, N., Turtzo, L.C., and Frank, J.A. (2016). Radiological-pathological correlation of diffusion tensor and magnetization transfer imaging in a closed head traumatic brain injury model. Ann. Neurol. 79, 907-920.

299. Tu, T.W., Lescher, J.D., Williams, R.A., Jikaria, N., Turtzo, L.C., and Frank, J.A. (2017). Abnormal injury response in spontaneous mild ventriculomegaly Wistar rat brains: a pathological correlation study of diffusion tensor and magnetization transfer imaging in mild traumatic brain injury. J. Neurotrauma 34, 248-256.

300. Tu, T.W., Ibrahim, W.G., Jikaria, N., Munasinghe, J.P., Witko, J.A., Hammoud, D.A., and Frank, J.A. (2018). On the detection of cerebral metabolic depression in experimental traumatic brain injury using Chemical Exchange Saturation Transfer (CEST)-weighted MRI. Sci. Rep. 8, 669

301. Tweedie, D., Rachmany, L., Rubovitch, V., Lehrmann, E., Zhang, Y.Q., Becker, K.G., Perez, E., Miller, J., Hoffer, B.J., Greig, N.H., and Pick, C.G. (2013). Exendin-4, a glucagon-like peptide-1 receptor agonist prevents mTBI-induced changes in hippocampus gene expression and memory deficits in mice. Exp. Neurol. 239, $170-182$.

302. Tweedie, D., Rachmany, L., Kim, D.S., Rubovitch, V., Lehrmann, E., Zhang, Y.Q., Becker, K.G., Perez, E., Pick, C.G., and Greig, N.H. (2016). Mild traumatic brain injury-induced hippocampal gene expressions: the identification of target cellular processes for drug development. J. Neurosci. Methods 272, 4-18.

303. Umschweif, G., Alexandrovich, A.G., Trembovler, V., Horowitz, M., and Shohami, E. (2013). The role and dynamics of beta-catenin in precondition induced neuroprotection after traumatic brain injury. PLoS One 8, e76129.

304. Umschweif, G., Liraz-Zaltsman, S., Shabashov, D., Alexandrovich, A., Trembovler, V., Horowitz, M., and Shohami, E. (2014). Angiotensin receptor type 2 activation induces neuroprotection and neurogenesis after traumatic brain injury. Neurotherapeutics 11 , 665-678

305. Vagnozzi, R., Marmarou, A., Tavazzi, B., Signoretti, S., Di Pierro, D., Del Bolgia, F., Amorini, A.M., Fazzina, G., Sherkat, S., and Lazzarino, G. (1999). Changes of cerebral energy metabolism and 
lipid peroxidation in rats leading to mitochondrial dysfunction after diffuse brain injury. J. Neurotrauma 16, 903-913.

306. Vagnozzi, R., Signoretti, S., Tavazzi, B., Cimatti, M., Amorini, A.M., Donzelli, S., Delfini, R., and Lazzarino, G. (2005). Hypothesis of the postconcussive vulnerable brain: experimental evidence of its metabolic occurrence. Neurosurgery 57, 164-171.

307. Vallez Garcia, D., Otte, A., Dierckx, R., and Doorduin, J. (2016). Three month follow-up of rat mild traumatic brain injury: a combined F-18 FDG and C-11 PK11195 positron emission study. J. Neurotrauma 33, 1855-1865.

308. van Rossem, K., Garcia-Martinez, S., De Mulder, G., Van Deuren, B., Engelborghs, K., Van Reempts, J., and Borgers, M. (1999). Brain oxygenation after experimental closed head injury. A NIRS study. Adv. Exp. Med. Biol. 471, 209-215.

309. Vannemreddy, P., Ray, A.K., Patnaik, R., Patnaik, S., Mohanty, S., and Sharma, H.S. (2006). Zinc protoporphyrin IX attenuates closed head injury-induced edema formation, blood-brain barrier disruption, and serotonin levels in the rat. Acta Neurochir. Suppl. 96, 151-156.

310. Venkatesan, C., Chrzaszcz, M., Choi, N., and Wainwright, M.S. (2010). Chronic upregulation of activated microglia immunoreactive for galectin-3/Mac-2 and nerve growth factor following diffuse axonal injury. J. Neuroinflammation 7, 32.

311. Vermeij, J.D., Aslami, H., Fluiter, K., Roelofs, J.J., van den Bergh, W.M., Juffermans, N.P., Schultz, M.J., Van der Sluijs, K., van de Beek, D., and van Westerloo, D.J. (2013). Traumatic brain injury in rats induces lung injury and systemic immune suppression. J. Neurotrauma 30, 2073-2079.

312. Villasana, L.E., Westbrook, G.L., and Schnell, E. (2014). Neurologic impairment following closed head injury predicts post-traumatic neurogenesis. Exp. Neurol. 261, 156-162.

313. Wang, H.C., Gao, J.L., Lassiter, T.F., McDonagh, D.L., Sheng, H.X., Warner, D.S., Lynch, J.R., and Laskowitz, D.T. (2006). Levetiracetam is neuroprotective in murine models of closed head injury and subarachnoid hemorrhage. Neurocrit. Care 5, 71-78.

314. Wang, Y., Guo, F., Pan, C.F., Lou, Y.L., Zhang, P.Q., Guo, S.C., Yin, J.H., and Deng, Z.F. (2012). Effects of low temperatures on proliferation-related signaling pathways in the hippocampus after traumatic brain injury. Exp. Biol. Med. 237, 1424-1432.

315. Wang, Y.C., Cui, Y., Cui, J.Z., Sun, L.Q., Cui, C.M., Zhang, H.A., Zhu, H.X., Li, R., Tian, Y.X., and Gao, J.L. (2015). Neuroprotective effects of brilliant blue $\mathrm{G}$ on the brain following traumatic brain injury in rats. Mol. Med. Rep. 12, 2149-2154.

316. Wang, C.X., Hu, Z.Y., Zou, Y., Xiang, M.J., Jiang, Y.T., Botchway, B.O.A., Huo, X., Du, X.X., and Fang, M.R. (2017). The posttherapeutic effect of rapamycin in mild traumatic brain-injured rats ensuing in the upregulation of autophagy and mitophagy. Cell. Biol. Int. $41,1039-1047$.

317. Watts, L.T., Sprague, S., Zheng, W., Garling, R.J., Jimenez, D., Digicaylioglu, M., and Lechleiter, J. (2013). Purinergic 2Y(1) receptor stimulation decreases cerebral edema and reactive gliosis in a traumatic brain injury model. J. Neurotrauma 30, 55-66.

318. Weckbach, S., Neher, M., Losacco, J.T., Bolden, A.L., Kulik, L., Flierl, M.A., Bell, S.E., Holers, V.M., and Stahel, P.F. (2012). Challenging the role of adaptive immunity in neurotrauma: $\operatorname{Rag} 1(-/-)$ mice lacking mature $\mathrm{B}$ and $\mathrm{T}$ cells do not show neuroprotection after closed head injury. J. Neurotrauma 29, 1233-1242.

319. White, E.R., Pinar, C., Bostrom, C.A., Meconi, A., and Christie, B.R. (2017). Mild traumatic brain injury produces long-lasting deficits in synaptic plasticity in the female juvenile hippocampus. J. Neurotrauma 34, 1111-1123.

320. Woodside, B., Robinson, B., and Amir, S. (1995). Induction of fos protein in a model of closed-head injury in rats. Brain Res. 690, $48-54$.

321. Xia, X.W., Dong, Y.W., Du, Y.Q., Yang, Y.D., Wang, W.B., and Li, Y. (2012). Relationship between learning and memory deficits and Arp2 expression in the hippocampus in rats with traumatic brain injury. World. Neurosurg. 78, 689-696.

322. Xu, L.Y., Nguyen, J.V., Lehar, M., Menon, A., Rha, E., Arena, J., Ryu, J., Marsh-Armstrong, N., Marmarou, C.R., and Koliatsos, V.E. (2016). Repetitive mild traumatic brain injury with impact acceleration in the mouse: multifocal axonopathy, neuroinflammation, and neurodegeneration in the visual system. Exp. Neurol. 275, 436-449.

323. Yaka, R., Biegon, A., Grigoriadis, N., Simeonidou, C., Grigoriadis, S., Alexandrovich, A.G., Matzner, H., Schumann, J., Trembovler, V., Tsenter, J., and Shohami, E. (2007). D-cycloserine improves func- tional recovery and reinstates long-term potentiation (LTP) in a mouse model of closed head injury. FASEB J. 21, 2033-2041.

324. Yamamoto, M., Marmarou, C.R., Stiefel, M.F., Beaumont, A., and Marmarou, A. (1999). Neuroprotective effect of hypothermia on neuronal injury in diffuse traumatic brain injury coupled with hypoxia and hypotension. J. Neurotrauma 16, 487-500.

325. Yan, E.B., Hellewell, S.C., Bellander, B.M., Agyapomaa, D.A., and Morganti-Kossmann, M.C. (2011). Post-traumatic hypoxia exacerbates neurological deficit, neuroinflammation and cerebral metabolism in rats with diffuse traumatic brain injury. J. Neuroinflammation $8,147$.

326. Yang, S.H., Gangidine, M., Pritts, T.A., Goodman, M.D., and Lentsch, A.B. (2013). Interleukin 6 mediates neuroinflammation and motor coordination deficits after mild traumatic brain injury and brief hypoxia in mice. Shock 40, 471-475.

327. Yang, S.H., Gustafson, J., Gangidine, M., Stepien, D., Schuster, R., Pritts, T.A., Goodman, M.D., Remick, D.G., and Lentsch, A.B. (2013). A murine model of mild traumatic brain injury exhibiting cognitive and motor deficits. J. Surg. Res. 184, 981-988.

328. Yatsiv, I., Grigoriadis, N., Simeonidou, C., Stahel, P.F., Schmidt, O.I., Alexandrovitch, A.G., Tsenter, J., and Shohami, E. (2005). Erythropoietin is neuroprotective, improves functional recovery, and reduces neuronal apoptosis and inflammation in a rodent model of experimental closed head injury. FASEB J. 19, 1701-1703.

329. Zaltzman, R., Alexandrovich, A., Trembovler, V., Shohami, E., and Gozes, I. (2005). The influence of the peptide NAP on Mac-1deficient mice following closed head injury. Peptides 26, 1520-1527.

330. Zhang, R.L., Shohami, E., BeitYannai, E., Bass, R., Trembovler, V., and Samuni, A. (1998). Mechanism of brain protection by nitroxide radicals in experimental model of closed-head injury. Free Radic. Biol. Med. 24, 332-340.

331. Zhang, H.S., Li, H., Zhang, D.D., Yan, H.Y., Zhang, Z.H., Zhou, C.H., Ye, Z.N., Chen, Q., Jiang, T.W., Liu, J.P., and Hang, C.H. (2016). Inhibition of myeloid differentiation factor 88(MyD88) by ST2825 provides neuroprotection after experimental traumatic brain injury in mice. Brain Res. 1643, 130-139.

332. Zhang, S., Kojic, L., Tsang, M., Grewal, P., Liu, J., Namjoshi, D., Wellington, C.L., Tetzlaff, W., Cynader, M.S., and Jia, W. (2016). Distinct roles for metalloproteinases during traumatic brain injury. Neurochem. Int. 96, 46-55.

333. Zhang, J., Huang, P., Wang, Z.Y., and Dong, H.M. (2017). Application of FTIR spectroscopy for traumatic axonal injury: a possible tool for estimating injury interval. Biosci. Rep. 37. pii: BSR20170720. doi: 10.1042/BSR20170720. Print 2017 Aug 31.

334. Zhou, Y., and Riccio, D.C. (1995). Concussion-induced retrograde amnesia in rats. Physiol. Behav. 57, 1107-1115.

335. Zhu, X.X., Park, J., Golinski, J., Qiu, J.H., Khuman, J., Lee, C.C.H., Lo, E.H., Degterev, A., and Whalen, M.J. (2014). Role of Akt and mammalian target of rapamycin in functional outcome after concussive brain injury in mice. J. Cereb. Blood Flow Metab. 34, 15311539.

336. Ziebell, J.M., Bye, N., Semple, B.D., Kossmann, T., and MorgantiKossmann, M.C. (2011). Attenuated neurological deficit, cell death and lesion volume in Fas-mutant mice is associated with altered neuroinflammation following traumatic brain injury. Brain Res. 1414, 94-105.

337. Zlotnik, A., Klin, Y., Kotz, R., Dubilet, M., Boyko, M., Ohayon, S., Shapira, Y., and Teichberg, V.I. (2010). Regulation of blood Lglutamate levels by stress as a possible brain defense mechanism. Exp. Neurol. 224, 465-471.

338. Zlotnik, A., Klin, Y., Gruenbaum, B.F., Gruenbaum, S.E., Ohayon, S., Leibowitz, A., Kotz, R., Dubilet, M., Boyko, M., Shapira, Y., and Teichberg, V.I. (2012). $\beta 2$ adrenergic-mediated reduction of blood glutamate levels and improved neurological outcome after traumatic brain injury in rats. J. Neurosurg. Anesthesiol. 24, 30-38.

339. Zlotnik, A., Sinelnikov, I., Gruenbaum, B.F., Gruenbaum, S.E., Dubilet, M., Dubilet, E., Leibowitz, A., Ohayon, S., Regev, A., Boyko, M., Shapira, Y., and Teichberg, V.I. (2012). Effect of glutamate and blood glutamate scavengers oxaloacetate and pyruvate on neurological outcome and pathohistology of the hippocampus after traumatic brain injury in rats. Anesthesiology 116, 73-83.

340. Zohar, O., Schreiber, S., Getslev, V., Schwartz, J.P., Mullins, P.G., and Pick, C.G. (2003). Closed-head minimal traumatic brain injury produces long-term cognitive deficits in mice. Neuroscience 118, 949-955. 
341. Zohar, O., Getslev, V., Miller, A.L., Schreiber, S., and Pick, C.G. (2006). Morphine protects for head trauma induced cognitive deficits in mice. Neurosci. Lett. 394, 239-242.

342. Zohar, O., Lavy, R., Zi, X.M., Nelson, T.J., Hongpaisan, J., Pick, C.G., and Alkon, D.L. (2011). PKC activator therapeutic for mild traumatic brain injury in mice. Neurobiol. Dis. 41, 329-337.

343. Zohar, O., Rubovitch, V., Milman, A., Schreiber, S., and Pick, C.G. (2011). Behavioral consequences of minimal traumatic brain injury in mice. Acta Neurobiol. Exp. (Wars.) 71, 36-45.

344. Bachstetter, A.D., Webster, S.J., Goulding, D.S., Morton, J.E., Watterson, D.M., and Van Eldik, L.J. (2015). Attenuation of traumatic brain injury-induced cognitive impairment in mice by targeting increased cytokine levels with a small molecule experimental therapeutic. J. Neuroinflammation 12, 69

345. Bayly, P.V., Dikranian, K.T., Black, E.E., Young, C., Qin, Y.Q., Labruyere, J., and Olney, J.W. (2006). Spatiotemporal evolution of apoptotic neurodegeneration following traumatic injury to the developing rat brain. Brain Res. 1107, 70-81.

346. Browning, J.R., Whiteman, A.C., Leung, L.Y., Lu, X.M., and Shear, D.A. (2017). Air-puff induced vocalizations: a novel approach to detecting negative affective state following concussion in rats. J. Neurosci. Methods 275, 45-49.

347. Chrzaszcz, M., Venkatesan, C., Dragisic, T., Watterson, D.M., and Wainwright, M.S. (2010). Minozac treatment prevents increased seizure susceptibility in a mouse "two-hit", model of closed skull traumatic brain injury and electroconvulsive shock-induced seizures. J. Neurotrauma 27, 1283-1295.

348. Coe, J.E., and Angyan, A.J. (1971). The effect of hyperbaric oxygenation upon recovery of maze performance after experimental concussion. J. Trauma 11, 436-439.

349. Creed, J.A., DiLeonardi, A.M., Fox, D.P., Tessler, A.R., and Raghupathi, R. (2011). Concussive brain trauma in the mouse results in acute cognitive deficits and sustained impairment of axonal function. J. Neurotrauma 28, 547-563.

350. Dikranian, K., Cohen, R., Mac Donald, C., Pan, Y., Brakefield, D., Bayly, P., and Parsadanian, A. (2008). Mild traumatic brain injury to the infant mouse causes robust white matter axonal degeneration which precedes apoptotic death of cortical and thalamic neurons. Exp. Neurol. 211, 551-560.

351. Dyck, A.C.F., and Ivanco, T.L. (2018). BDNF expression increases without changes in play behavior following concussion in juvenile rats (Rattus norvegicus): brief report. Dev. Neurorehabil. 21, $1-5$.

352. Emmerich, T., Abdullah, L., Ojo, J., Mouzon, B., Nguyen, T., Laco, G.S., Crynen, G., Evans, J.E., Reed, J., Mullan, M., and Crawford, F. (2017). Mild TBI results in a long-term decrease in circulating phospholipids in a mouse model of injury. Neuromolecular Med. 19 122-135.

353. Erturk, A., Mentz, S., Stout, E.E., Hedehus, M., Dominguez, S.L., Neumaier, L., Krammer, F., Llovera, G., Srinivasan, K., Hansen, D.V., Liesz, A., Scearce-Levie, K.A., and Sheng, M. (2016). Interfering with the chronic immune response rescues chronic degeneration after traumatic brain injury. J. Neurosci. 36, 9962-9975.

354. Goodus, M.T., Kerr, N.A., Talwar, R., Buziashvili, D., Fragale, J.E.C., Pang, K.C.H., and Levison, S.W. (2016). Leukemia inhibitory factor haplodeficiency desynchronizes glial reactivity and exacerbates damage and functional deficits after a concussive brain injury. J. Neurotrauma 33, 1522-1534.

355. Grin'kina, N.M., Li, Y., Haber, M., Sangobowale, M., Nikulina, E. Le'Pre, C., El Sehamy, A.M., Dugue, R., Ho, J.S., and Bergold, P.J. (2016). Righting reflex predicts long-term histological and behavioral outcomes in a closed head model of traumatic brain injury. PLoS One 11, e0161053.

356. Hanlon, L.A., Raghupathi, R., and Huh, J.W. (2017). Differential effects of minocycline on microglial activation and neurodegeneration following closed head injury in the neonate rat. Exp. Neurol. 290, 1-14.

357. Hehar, H., and Mychasiuk, R. (2016). The use of telomere length as a predictive biomarker for injury prognosis in juvenile rats following a concussion/mild traumatic brain injury. Neurobiol. Dis. 87, 11-18.

358. Hernandez, A., Donovan, V., Grinberg, Y.Y., Obenaus, A., and Carson, M.J. (2016). Differential detection of impact site versus rotational site injury by magnetic resonance imaging and microglial morphology in an unrestrained mild closed head injury model. J. Neurochem. 136, 18-28.
359. Jeong, S., Lei, B.L., Wang, H.C., Dawson, H.N., and James, M.L. (2014). Intravenous immunoglobulin $\mathrm{G}$ improves neurobehavioral and histological outcomes after traumatic brain injury in mice. J. Neuroimmunol. 276, 112-118.

360. Karelina, K., Gaier, K.R., Prabhu, M., Wenger, V., Corrigan, T.E.D., and Weil, Z.M. (2017). Binge ethanol in adulthood exacerbates negative outcomes following juvenile traumatic brain injury. Brain Behav. Immun. 60, 304-311.

361. Laskowitz, D.T., McKenna, S.E., Song, P.P., Wang, H.C., Durham, L., Yeung, N., Christensen, D., and Vitek, M.P. (2007). COG1410, a novel apolipoprotein E-based peptide, improves functional recovery in a murine model of traumatic brain injury. J. Neurotrauma 24 , 1093-1107.

362. Laskowitz, D.T., Song, P.P., Wang, H.C., Mace, B., Sullivan, P.M., Vitek, M.P., and Dawson, H.N. (2010). Traumatic brain injury exacerbates neurodegenerative pathology: improvement with an apolipoprotein E-based therapeutic. J. Neurotrauma 27, 1983-1995.

363. Leinenweber, S.B., Sheng, H., Lynch, J.R., Wang, H., BatinicHaberle, I., Laskowitz, D.T., Crapo, J.D., Pearlstein, R.D., and Warner, D.S. (2006). Effects of a manganese (III) porphyrin catalytic antioxidant in a mouse closed head injury model. Eur. J. Pharmacol. 531, 126-132.

364. Lloyd, E., Somera-Molina, K., Van Eldik, L.J., Watterson, D.M., and Wainwright, M.S. (2008). Suppression of acute proinflammatory cytokine and chemokine upregulation by post-injury administration of a novel small molecule improves long-term neurologic outcome in a mouse model of traumatic brain injury. J. Neuroinflammation 5, 26.

365. Lynch, J.R., Pineda, J.A., Morgan, D., Zhang, L., Warner, D.S., Benveniste, H., and Laskowitz, D.T. (2002). Apolipoprotein E affects the central nervous system response to injury and the development of cerebral edema. Ann. Neurol. 51, 113-117.

366. Lynch, J.R., Wang, H., Mace, B., Leinenweber, S., Warner, D.S., Bennett, E.R., Vitek, M.P., McKenna, S., and Laskowitz, D.T (2005). A novel therapeutic derived from apolipoprotein $E$ reduces brain inflammation and improves outcome after closed head injury. Exp. Neurol. 192, 109-116.

367. Maruichi, K., Kuroda, S., Chiba, Y., Hokari, M., Shichinohe, H., Hida, K., and Iwasaki, Y. (2009). Graded model of diffuse axonal injury for studying head injury-induced cognitive dysfunction in rats. Neuropathology 29, 132-139.

368. Mierzwa, A.J., Marion, C.M., Sullivan, G.M., McDaniel, D.P., and Armstrong, R.C. (2015). Components of myelin damage and repair in the progression of white matter pathology after mild traumatic brain injury. J. Neuropathol. Exp. Neurol. 74, 218-232.

369. Mychasiuk, R., Farran, A., and Esser, M.J. (2014). Assessment of an experimental rodent model of pediatric mild traumatic brain injury. J. Neurotrauma 31, 749-757.

370. Nawashiro, H., Shima, K., and Chigasaki, H. (1995). Selective vulnerability of hippocampal CA3 neurons to hypoxia after mild concussion in the rat. Neurol. Res 17, 455-460.

371. Nilsson, B., and Ponten, U. (1977). Exerimental head injury in the rat. Part 2: regional brain energy metabolism in concussive trauma. J. Neurosurg. 47, 252-261.

372. Ohayon, S., Boyko, M., Saad, A., Douvdeyani, A., Gruenbaum, B.F., Melamed, I., Shapira, Y., Teichberg, V.I., and Zlotnik, A. (2012) Cell-free DNA as a marker for prediction of brain damage in traumatic brain injury in rats. J. Neurotrauma 29, 261-267.

373. Reshef, A., Shirvan, A., Shohami, E., Grimberg, H., Levin, G., Cohen, A., Trembovler, V., and Ziv, I. (2008). Targeting cell death in vivo in experimental traumatic brain injury by a novel molecular probe. J Neurotrauma 25, 569-580.

374. Romano, J., Beni-Adani, L., Nissenbaum, O.L., Brenneman, D.E., Shohami, E. and Gozes, I. (2002). A single administration of the peptide NAP induces long-term protective changes against the consequences of head injury: gene Atlas array analysis. J. Mol. Neurosci. 18, 37-45.

375. Rostami, E., Davidsson, J., Gyorgy, A., Agoston, D.V., Risling, M., and Bellander, B.M. (2013). The terminal pathway of the complement system is activated in focal penetrating but not in mild diffuse traumatic brain injury. J. Neurotrauma 30, 1954-1965.

376. Rubenstein, R., Wang, K.K., Chiu, A., Grinkina, N., Sharma, D.R., Agarwal, S., Lin, F., and Yang, Z.H. (2018). PrPc expression and calpain activity independently mediate the effects of closed head injury in mice. Behav. Brain Res. 340, 29-40. 
377. Rubovitch, V., Edut, S., Sarfstein, R., Werner, H., and Pick, C.G. (2010). The intricate involvement of the Insulin-like growth factor receptor signaling in mild traumatic brain injury in mice. Neurobiol. Dis. 38, 299-303.

378. Schaller, W.F., Tamaki, K., and Newman, H.W. (1941). Petechial hemorrhages of the brain-experimentally produced in rats by concussion. Arch. Neurol. Psychiatry 45, 1-23.

379. Schwulst, S.J., Trahanas, D.M., Saber, R., and Perlman, H. (2013). Traumatic brain injury-induced alterations in peripheral immunity. J. Trauma Acute Care Surg. 75, 780-788.

380. Shishido, H., Kishimoto, Y., Kawai, N., Toyota, Y., Ueno, M., Kubota, T., Kirino, Y., and Tamiya, T. (2016). Traumatic brain injury accelerates amyloid-beta deposition and impairs spatial learning in the triple-transgenic mouse model of Alzheimer's disease. Neurosci. Lett. 629, 62-67.

381. Verdonck, O., Lahrech, H., Francony, G., Carle, O., Farion, R., Van de Looij, Y., Remy, C., Segebarth, C., and Payen, J.F. (2007). Erythropoietin protects from post-traumatic edema in the rat brain. J. Cereb. Blood Flow Metab. 27, 1369-1376.

382. Wang, H.C., Lynch, J.R., Song, P.P., Yang, H.J., Yales, R.B., Mace, B., Warner, D.S., Guyton, J.R., and Laskowitz, D.T. (2007). Simvastatin and atorvastatin improve behavioral outcome, reduce hippocampal degeneration, and improve cerebral blood flow after experimental traumatic brain injury. Exp. Neurol. 206, 59-69.

383. Wang, T., Chou, D.Y.T., Ding, J.Y., Fredrickson, V., Peng, C.Y., Schafer, S., Guthikonda, M., Kreipke, C., Rafols, J.A., and Ding, Y.C. (2013). Reduction of brain edema and expression of aquaporins with acute ethanol treatment after traumatic brain injury. J. Neurosurg. 118, 390-396.

384. Webster, S.J., Van Eldik, L.J., Watterson, D.M., and Bachstetter, A.D. (2015). Closed head injury in an age-related Alzheimer mouse model leads to an altered neuroinflammatory response and persistent cognitive impairment. J. Neurosci. 35, 6554-6569.

385. Weil, Z.M., Karelina, K., Gaier, K.R., Corrigan, T.E.D., and Corrigan, J.D. (2016). Juvenile traumatic brain injury increases alcohol consumption and reward in female mice. J. Neurotrauma 33, 895-903.

386. Wendel, K.M., Lee, J.B., Affeldt, B., Hamer, M., Harahap-Carrillo, I.S., Pardo, A.C., and Obenaus, A. (2018). Corpus callosum vasculature predicts white matter microstructure abnormalities following pediatric mild traumatic brain injury. J. Neurotrauma. Jul 23. doi: 10.1089/neu.2018.5670. [Epub ahead of print]

387. Chen, Z.Y., Leung, L.Y., Mountney, A., Liao, Z.L., Yang, W.H., Lu, X.C.M., Dave, J., Deng-Bryant, Y., Wei, G., Schmid, K., Shear, D.A., and Tortella, F.C. (2012). A novel animal model of closedhead concussive-induced mild traumatic brain injury: development, implementation, and characterization. J. Neurotrauma 29, 268-280.

388. Ellingson, B.M., Fijalkowski, R.J., Pintar, F.A., Yoganandan, N., and Gennarelli, T.A. (2005). New mechanism for inducing closed head injury in the rat. Biomed. Sci. Instrum. 41, 86-91.

389. Fijalkowski, R.J., Stemper, B.D., Pintar, F.A., Yoganandan, N., Crowe, M.J., and Gennarelli, T.A. (2007). New rat model for diffuse brain injury using coronal plane angular acceleration. J. Neurotrauma 24, 1387-1398.

390. Henry, J.M., Talukder, N.K., Lee, A.B., and Walker, M.L. (1997). Cerebral trauma-induced changes in corpus striatal dopamine receptor subtypes. J. Invest. Surg. 10, 281-286.

391. Herrera, J.J., Bockhorst, K., Kondraganti, S., Stertz, L., Quevedo, J., and Narayana, P.A. (2017). Acute white matter tract damage after frontal mild traumatic brain injury. J. Neurotrauma 34, 291-299.

392. Huger, F., and Patrick, G. (1979). Effect of concussive head injury on central catecholamine levels and synthesis rates in rat brain regions. J. Neurochem. 33, 89-95.

393. Kilbourne, M., Kuehn, R., Tosun, C., Caridi, J., Keledjian, K., Bochicchio, G., Scalea, T., Gerzanich, V., and Simard, J.M. (2009). Novel model of frontal impact closed head injury in the rat. J. Neurotrauma 26, 2233-2243.

394. Kmieciak-Kolada, K., Felinska, W., Stachura, Z., Majchrzak, H. and Herman, Z.S. (1987). Concentration of biogenic amines and their metabolites in different parts of brain after experimental cerebral concussion. Pol. J. Pharmacol. Pharm. 39, 47-53.

395. Leung, L.Y., Larimore, Z., Holmes, L., Cartagena, C., Mountney, A., Deng-Bryant, Y., Schmid, K., Shear, D., and Tortella, F. (2014). The WRAIR projectile concussive impact model of mild traumatic brain injury: re-design, testing and preclinical validation. Ann. Biomed. Eng. 42, 1618-1630.
396. Li, Y., Bader, M., Tamargo, I., Rubovitch, V., Tweedie, D., Pick, C.G., and Greig, N.H. (2015). Liraglutide is neurotrophic and neuroprotective in neuronal cultures and mitigates mild traumatic brain injury in mice. J. Neurochem. 135, 1203-1217.

397. Liang, F., Luo, C., Xu, G., Su, F., He, X., Long, S., Ren, H., Liu, Y., Feng, Y., and Pei, Z. (2015). Deletion of aquaporin-4 is neuroprotective during the acute stage of micro traumatic brain injury in mice. Neurosci. Lett. 598, 29-35.

398. Morehead, M., Bartus, R.T., Dean, R.L., Miotke, J.A., Murphy, S., Sall, J., and Goldman, H. (1994). Histopathologic consequences of moderate concussion in an animal model: correlations with duration of unconsciousness. J. Neurotrauma 11, 657-667.

399. Ongali, R., Hellal, F., Rodi, D., Plotkine, M., Marchand-Verrecchia, C., Pruneau, D., and Couture, R. (2006). Autoradiographic analysis of mouse brain kinin B-1 and B-2 receptors after closed head trauma and ability of anatibant mesylate to cross the blood-brain barrier. $\mathrm{J}$. Neurotrauma 23, 696-707.

400. Ren, Z.G., Iliff, J.J., Yang, L.J., Yang, J.K., Chen, X.L., Chen, M.J., Giese, R.N., Wang, B.Z., Shi, X.F., and Nedergaard, M. (2013). 'Hit \& Run' model of closed-skull traumatic brain injury (TBI) reveals complex patterns of post-traumatic AQP4 dysregulation. J. Cereb. Blood Flow Metab. 33, 834-845.

401. Rostami, E., Davidsson, J., Ng, K.C., Lu, J., Gyorgy, A., Walker, J., Wingo, D., Plantman, S., Bellander, B.M., Agoston, D.V., and Risling, M. (2012). A model for mild traumatic brain injury that induces limited transient memory impairment and increased levels of axon related serum biomarkers. Front. Neurol. 3, 115.

402. Rozas, N.S., Redell, J.B., Hill, J.L., McKenna, J., Moore, A.N., Gambello, M.J., and Dash, P.K. (2015). Genetic activation of mTORC1 signaling worsens neurocognitive outcome after traumatic brain injury. J. Neurotrauma 32, 149-158.

403. Schneider, B.L., Ghoddoussi, F., Charlton, J.L., Kohler, R.J., Galloway, M.P., Perrine, S.A., and Conti, A.C. (2016). Increased cortical gamma-aminobutyric acid precedes incomplete extinction of conditioned fear and increased hippocampal excitatory tone in a mouse model of mild traumatic brain injury. J. Neurotrauma 33, 1614-1624.

404. Sengul, G., Takci, E., Malcok, U.A., Akar, A., Erdogan, F., Kadioglu, H.H., and Aydin, I.H. (2008). A preliminary histopathological study of the effect of agmatine on diffuse brain injury in rats. J. Clin. Neurosci. 15, 1125-1129.

405. Shaw, N.A., and Cant, B.R. (1984). The effect of experimental concussion on somatosensory evoked potentials. Aust. J. Exp. Biol. Med. Sci. 62, Pt. 3, 361-371.

406. Shaw, N.A. (1986). Somatosensory evoked potentials after experimental head injury in the awake rat. J. Neurol. Sci. 74, 257-270.

407. Shaw, N.A. (1988). The effects of experimental concussion on cervical and thalamic somatosensory evoked potentials. Electromyogr. Clin. Neurophysiol. 28, 67-73.

408. Shein, N.A., Grigoriadis, N., Alexandrovich, A.G., Simeonidou, C., Lourbopoulos, A., Polyzoidou, E., Trembovler, V., Mascagni, P., Dinarello, C.A., and Shohami, E. (2009). Histone deacetylase inhibitor ITF2357 is neuroprotective, improves functional recovery, and induces glial apoptosis following experimental traumatic brain injury. FASEB J. 23, 4266-4275.

409. Stemper, B.D., Shah, A.S., Pintar, F.A., McCrea, M., Kurpad, S.N., Glavaski-Joksimovic, A., Olsen, C., and Budde, M.D. (2015). Head rotational acceleration characteristics influence behavioral and diffusion tensor imaging outcomes following concussion. Ann. Biomed. Eng. 43, 1071-1088.

410. Stone, J.R., Singleton, R.H., and Povlishock, J.T. (2000). Antibodies to the C-terminus of the beta-amyloid precursor protein (APP): a site specific marker for the detection of traumatic axonal injury. Brain Res. 871, 288-302.

411. Wirth, P., Yu, W.L., Kimball, A.L., Liao, J., Berkner, P., and Glenn, M.J. (2017). New method to induce mild traumatic brain injury in rodents produces differential outcomes in female and male Sprague Dawley rats. J. Neurosci. Methods 290, 133-144.

412. Chen, Y., Constantini, S., Trembovler, V., Weinstock, M., and Shohami, E. (1996). An experimental model of closed head injury in mice: pathophysiology, histopathology, and cognitive deficits. J. Neurotrauma 13, 557-568.

413. Wirth, P., Yu, W., Kimball, A.L., Liao, J., Berkner, P., and Glenn, M.J. (2017). New method to induce mild traumatic brain injury in rodents produces differential outcomes in female and male Sprague Dawley rats. J. Neurosci. Methods 290, 133-144. 
414. Lighthall, J.W., Dixon, C.E., and Anderson, T.E. (1989). Experimental models of brain injury. J. Neurotrauma 6, 83-97.

415. Xiong, Y., Mahmood, A., and Chopp, M. (2013). Animal models of traumatic brain injury. Nat. Rev. Neurosci. 14, 128-142.

416. Bolouri, H., and Zetterberg, H. (2015). Animal models for concussion: molecular and cognitive assessments-revelance to sport and military concussions, in: Brain Neurotrauma. F.H. Kobeissy (ed). Taylor \& Francis: Boca Raton, FL.

417. Petraglia, A.L., Dashnaw, M.L., Turner, R.C. and Bailes, J.E. (2014). Models of mild traumatic brain injury: translation of physiological and anatomic injury. Neurosurgery 75, Suppl. 4 , S34-S49.

418. Cernak, I., Stein, D.G., Elder, G.A., Ahlers, S., Curley, K., DePalma, R.G., Duda, J., Ikonomovic, M., Iverson, G.L., Kobeissy, F., Koliatsos, V.E., Leggieri, M.J., Jr., Pacifico, A.M., Smith, D.H., Swanson, R., Thompson, F.J., and Tortella, F.C. (2017). Preclinical modelling of militarily relevant traumatic brain injuries: challenges and recommendations for future directions. Brain Inj. 31, 1168-1176.

419. Gennarelli, T.A. (1994). Animate models of human head injury. J. Neurotrauma 11, 357-368.

420. DeWitt, D.S., Hawkins, B.E., Dixon, C.E., Kochanek, P.M., Armstead, W., Bass, C.R., Bramlett, H.M., Buki, A., Dietrich, W.D., Ferguson, A.R., Hall, E.D., Hayes, R.L., Hinds, S.R., LaPlaca, M.C., Long, J.B., Meaney, D.F., Mondello, S., Noble-Haeusslein, L.J., Poloyac, S.M., Prough, D.S., Robertson, C.S., Saatman, K.E., Shultz S.R., Shear, D.A., Smith, D.H., Valadka, A.B., VandeVord, P., and Zhang, L. (2018). Pre-clinical testing of therapies for traumatic brain injury. J. Neurotrauma 35, 2737-2754.

421. Johnson, V.E., Meaney, D.F., Cullen, D.K., and Smith, D.H. (2015) Animal models of traumatic brain injury. Handb. Clin. Neurol. 127 $115-128$.

422. Morales, D.M., Marklund, N., Lebold, D., Thompson, H.J., Pitkanen, A., Maxwell, W.L., Longhi, L., Laurer, H., Maegele, M., Neugebauer, E., Graham, D.I., Stocchetti, N., and McIntosh, T.K. (2005). Experimental models of traumatic brain injury: do we really need to build a better mousetrap? Neuroscience 136, 971-989.
423. Morganti-Kossmann, M.C., Yan, E., and Bye, N. (2010). Anima models of traumatic brain injury: Is there an optimal model to reproduce human brain injury in the laboratory? Injury 41, Suppl. 1, S10-S13.

424. Dixon, C.E., Clifton, G.L., Lighthall, J.W., Yaghmai, A.A., and Hayes, R.L. (1991). A controlled cortical impact model of traumatic brain injury in the rat. J. Neurosci. Methods 39, 253-262.

425. Brody, D.L., Mac Donald, C., Kessens, C.C., Yuede, C., Parsadanian, M., Spinner, M., Kim, E., Schwetye, K.E., Holtzman, D.M., and Bayly, P.V. (2007). Electromagnetic controlled cortical impact device for precise, graded experimental traumatic brain injury. J. Neurotrauma 24, 657-673.

426. Zhang, L., Gurao, M., Yang, K.H., and King, A.I. (2011). Material characterization and computer model simulation of low density polyurethane foam used in a rodent traumatic brain injury model. $\mathbf{J}$ Neurosci. Methods 198, 93-98.

427. Pleasant, J.M., Carlson, S.W., Mao, H., Scheff, S.W., Yang, K.H., and Saatman, K.E. (2011). Rate of neurodegeneration in the mouse controlled cortical impact model is influenced by impactor tip shape: implications for mechanistic and therapeutic studies. J. Neurotrauma 28, 2245-2262.

428. Farace, E., and Alves, W.M. (2000). Do women fare worse: a metaanalysis of gender differences in traumatic brain injury outcome. $\mathrm{J}$ Neurosurg. 93, 539-545.

429. Herson, P.S., Koerner, I.P., and Hurn, P.D. (2009). Sex, sex steroids, and brain injury. Semin. Reprod. Med. 27, 229-239.

Address correspondence to:

Adam D. Bachstetter, PhD

Department of Neuroscience

University of Kentucky

741 S. Limestone Street Lexington, KY 40536

E-mail: adam.bachstetter@uky.edu 